\title{
Developmental programming of insulin resistance: are androgens the culprits?
}

\author{
Muraly Puttabyatappa ${ }^{1}$, Robert M Sargis ${ }^{2}$ and Vasantha Padmanabhan ${ }^{1}$ \\ 1Department of Pediatrics, University of Michigan, Ann Arbor, Michigan, USA \\ 2Department of Medicine, University of Illinois at Chicago, Chicago, Illinois, USA
}

Correspondence should be addressed to V Padmanabhan: vasantha@umich.edu

\begin{abstract}
Insulin resistance is a common feature of many metabolic disorders. The dramatic rise in the incidence of insulin resistance over the past decade has enhanced focus on its developmental origins. Since various developmental insults ranging from maternal disease, stress, over/undernutrition, and exposure to environmental chemicals can all program the development of insulin resistance, common mechanisms may be involved. This review discusses the possibility that increases in maternal androgens associated with these various insults are key mediators in programming insulin resistance.

Additionally, the intermediaries through which androgens misprogram tissue insulin sensitivity, such as changes in inflammatory, oxidative, and lipotoxic states, epigenetic, gut microbiome and insulin, as well as data gaps to be filled are also discussed.
\end{abstract} Key Words

- fetal

- steroids

- androgen antagonist

- insulin sensitizer

\section{Introduction}

Insulin resistance is a characteristic feature of many metabolic disorders, including the metabolic syndrome, type 2 diabetes mellitus (T2DM), obesity, non-alcoholic fatty liver disease (NAFLD), polycystic ovary syndrome (PCOS), gestational diabetes mellitus, and others. Traditionally, genetics and lifestyle are considered the main contributors to the development of these disorders of insulin resistance (Nilsson \& Ling 2017, Zheng et al. 2018). However, the dramatic rise in incidence of this pathology during the last decades cannot be adequately explained by genetic predisposition and lifestyle changes alone. Accumulating evidence suggests factors acting during early fetal development are additional contributors (Franks et al. 2013, Vaiserman \& Lushchak 2019). As fetal growth and differentiation are largely dependent on the maternal and intrauterine hormonal milieu during early development, hormones and factors that change the hormonal milieu during the fetal ontogeny may have an important role in the development of insulin resistance.
Hormonal influences during fetal differentiation are so critical that even mild and transient changes in maternal and intrauterine hormone levels within accepted physiological limits can affect the trajectory of normal fetal growth (Miranda \& Sousa 2018). Of these hormones, steroid hormones play a significant and widespread role in the long-term organization of fetal organ systems (Fowden \& Forhead 2004, Seckl \& Holmes 2007).

Steroidal influences on tissue organization stem from the plasticity of the fetus, a feature entrenched in the physiological process of fetal development and differentiation, which is most clearly evident in the process of sexual differentiation. Prior to sexual differentiation primitive gonads and reproductive structures are bipotential, and based on the genetic sex and under the influence of sex hormones, they develop into either male or female gonads and reproductive organs (Jost et al. 1973, Jost 1983). The presence of the Y chromosome in the male, for example, leads to production of 
testis-determining factor (TDF/sex-determining region $\mathrm{Y}$ (SRY)), a transcription factor that directs the development of bipotential gonads into testes. The developing testes produce hormones, including Mullerian-inhibiting substance/anti-Mullerian hormone (MIS/AMH) and testosterone. This hormonal milieu induces regression of the Mullerian ducts, which are otherwise destined to form female reproductive structures, and promotes the development of Wolffian ducts into male reproductive structures. The steroid hormone testosterone further promotes maturation of these structures and organization of the reproductive neuroendocrine axis and reproductive behavior. Gonadal sexual differentiation begins early in gestation in humans (Rabinovici \& Jaffe 1990), and during this critical window, inappropriate exposure of the female fetus (XX chromosomal complement) to excess testosterone leads to virilization of reproductive organs and masculinization of reproductive behaviors (Berenbaum 2002). These observations are embedded in classical physiology and demonstrate the plasticity of the developing fetus and the importance of the maternal and fetal steroid hormone milieu in shaping fetal developmental trajectories (McEwen 1992).

This plasticity allows the fetus to respond to the prevailing maternal environment, which induces cellular and molecular changes to allow phenotypic adaptations. This process is termed 'developmental plasticity', and in theory aids in improving the offspring's chances for survival in the external environment (Laubach et al. 2018, Lema 2020). However, the organizational changes that allow short-term survival often prove to be maladaptive in the long term by augmenting risk for non-communicable diseases such as T2DM (Hales \& Barker 1992), metabolic syndrome (Rinaudo \& Wang 2012), and obesity (Breier et al. 2001). This concept has been formalized as the Developmental Origins of Health and Disease (DOHaD) hypothesis and is of relevance to many maternal and environmental insults (Barker 2004, 2007, Gluckman \& Hanson 2004, Wadhwa et al. 2009, Padmanabhan et al. 2010a, Barouki et al. 2012). Hormones, particularly steroid hormones, play a critical role in mediating the influence of these internal and external environmental signals and direct either adaptive or maladaptive responses in the developing fetus (Dufty et al. 2002).

Adaptive organizational changes often remain dormant, requiring an activational step to unmask the programmed phenotypic and behavioral changes. An example of such activational processes is evident in reproductive behavior. While the neurocircuitry required for reproductive behaviors is organized during early development, these pathways remain relatively quiescent prior to puberty, requiring subsequent stimulation by sex steroids to induce appropriate adult reproductive behavior (Romeo 2003). Similarly, the maladaptive organizations induced during early life in metabolic systems may remain dormant until activated by prevailing postnatal environmental cues, with hormones including steroids serving as mediators of this activational process (Puttabyatappa et al. 2016).

The reprogramming associated with fetal exposure to steroids at abnormal concentrations or at inappropriate times are often detrimental, culminating in a diverse array of adult pathologies. Inappropriate exposure to steroids can occur through disease, maternal stress, adverse maternal nutritional states, and environmental stressors, including exposure to chemicals with the potential to disrupt steroid hormone signaling (Padmanabhan et al. 2016). Since adverse conditions and exposures not only impact the maternal hormonal milieu but also the fetal hormonal environment, the placenta serves as a critical intermediary in this developmental process by acting as a conduit between the maternal and fetal compartments while also serving as a steroidogenic organ (Strauss et al. 1996, Wooding \& Burton 2008); thus, the placenta plays a critical role in regulating fetal exposures to maternal and environmental factors. Data from the Helsinki Birth Cohort have shown that abnormal placenta are linked with development of adult onset cardiometabolic diseases in the offspring (Thornburg et al. 2010). Therefore, conditions that compromise placental function either through direct maternal-fetal transfer or through altered placental steroidogenesis (e.g. preeclampsia, gestational diabetes, and endocrine-disrupting chemicals (EDCs)) (Nugent \& Bale 2015) contribute to inappropriate fetal exposure to steroids with potential consequences on fetal development and the long-term health of the offspring.

\section{Androgen programming of insulin resistance}

Insulin secreted from pancreatic beta-cells maintains postprandial nutrient homeostasis through stimulation of anabolic processes: increasing glucose influx into muscle and adipose tissue, protein and glycogen synthesis in muscle and liver, lipid synthesis and storage in liver and adipose tissue, and through inhibition of fatty acid oxidation, lipolysis, glycogenolysis, and gluconeogenesis (Guo 2014). A failure to respond to insulin and achieve these physiological effects defines insulin resistance and results in compensatory increases in beta-cell insulin 
secretion. Lack of responsiveness to insulin occurs at systemic, tissue, and cellular levels as a result of increases in inflammation, oxidative stress, hypoadiponectinemia, and dyslipidemia; all of which negatively affect insulin action and tissue function (Hocking et al. 2013, BurgosMoron et al. 2019, Iwabu et al. 2019). At the cellular level, reduced insulin response may result from insulin receptor desensitization or reduced expression, suppression of members of the insulin receptor signaling pathway and associated regulatory network, and mitochondrial and endoplasmic reticulum dysfunction (Flamment et al. 2012, Guo 2014, Gonzalez-Franquesa \& Patti 2017).

Developmental exposure to various insults can lead to programming of insulin resistance as evident from clinical, epidemiological, and experimental studies (Table 1). While steroid hormones can directly influence insulin action as evident from sex-specific differences in glucose homeostasis and adipose distribution (MauvaisJarvis 2015, Varlamov et al. 2015), the evidence that developmental insults can lead to changes in maternal steroids especially androgens (Table 2) and induce insulin resistance (Table 1) point to androgens as potential culprits in the developmental programming of insulin resistance. Examples of conditions that result in excessive maternal androgen exposure include virilizing congenital adrenal hyperplasia (CAH) and the PCOS. In $\mathrm{CAH}$, mutations in the 21-hydroxylase enzyme, which is required for biosynthesis of mineralocorticoids and glucocorticoids, results in androgen excess with consequential fetal exposure (Parsa \& New 2017); importantly, these offspring exhibit postnatal signs of reduced insulin sensitivity (Tamhane et al. 2018). Evidence indicates that during pregnancy women with PCOS have higher androgen levels with associated disruptions in placental steroidogenesis (Sir-Petermann et al. 2002, Maliqueo et al. 2013), which likely combine to result in excess fetal androgen exposure. Daughters of these women show signs of metabolic derangements, including hyperinsulinemia during adolescence (SirPetermann et al. 2009). Maternal stress not only increases maternal glucocorticoids levels (Dunkel Schetter 2011), but it also induces a hyperandrogenic maternal hormonal milieu (Barrett \& Swan 2015). A 30-year follow-up study reported hyperinsulinemia among offspring born to mothers administrated glucocorticoids during pregnancy (Dalziel et al. 2005). Maternal under- and over-nutrition have both been linked with the programming of obesity, T2DM, and insulin resistance (Duque-Guimaraes \& Ozanne 2013, Vaiserman 2017). In addition to direct effects of the altered nutritional state, these conditions also alter the maternal androgenic milieu (Mossa et al. 2019,
Pasquali \& Oriolo 2019). For example, maternal obesity is associated with increased androgen levels (Whyte et al. 2007, Arnon et al. 2016, Maliqueo et al. 2017, Pasquali \& Oriolo 2019), suggesting a potential role for androgens in the programming of offspring phenotypes in such nutritional models.

Environmental EDCs, especially those that have the capacity to influence androgen biosynthesis or bioavailability as well as those that modulate androgen receptor signaling, are also potential contributors to androgenic programming of metabolic disorders such as insulin resistance (Diamanti-Kandarakis et al. 2009, Gore et al. 2015). Rapid industrialization has led to widespread fetal and offspring exposure to EDCs through maternal-fetal transfer both across the placenta and via lactation, resulting in exposure during critical susceptibility windows (Masuda et al. 1978, Ando et al. 1985, Bowman \& Choudhury 2016). Many naturally occurring compounds (e.g. phytoestrogens, including genistein and coumestrol) as well as anthropogenic chemicals (e.g. industrial solvents and lubricants (e.g. polychlorinated biphenyls (PCBs), polybrominated biphenyls, and dioxins), plasticizers (e.g. bisphenol A (BPA)), pesticides (e.g. dichlorodiphenyltrichloroethane (DDT)), fungicides (e.g. vinclozolin), and pharmaceutical agents (e.g. diethylstilbestrol)) (Kabir et al. 2015) are EDCs that can serve as steroid mimics and activate steroid receptor signaling. Meta-analyses conducted by the National Toxicology Program and analyses of the National Health and Nutrition Examination Survey 2003-2004 data have shown strong associations between the incidence of T2DM and persistent organic pollutants (DDT and PCBs) and BPA (Lang et al. 2008, Taylor et al. 2013). Especially concerning is the fact that many of these EDCs are detectable in pregnant women and cord blood (Woodruff et al. 2011, Lee et al. 2017, Goodrich et al. 2019), thus suggesting the potential for these chemicals to disrupt fetal and offspring developmental trajectories. Maternal exposure to BPA and phthalates have been shown to alter maternal androgen milieu (Takeuchi et al. 2004, Sathyanarayana et al. 2017) raising the possibility that the programming effects of these EDCs may be mediated via alterations in the maternal androgenic milieu. Apart from their agonistic/antagonistic actions (De Falco et al. 2015), EDCs can indirectly affect the prevailing steroid milieu by modulating rate-limiting enzymes involved in steroid hormone biosynthesis and/ or metabolism (Sanderson 2006, Tabb \& Blumberg 2006). Evidence that EDCs affect steroid biosynthesis comes from data demonstrating reduced placental aromatase 


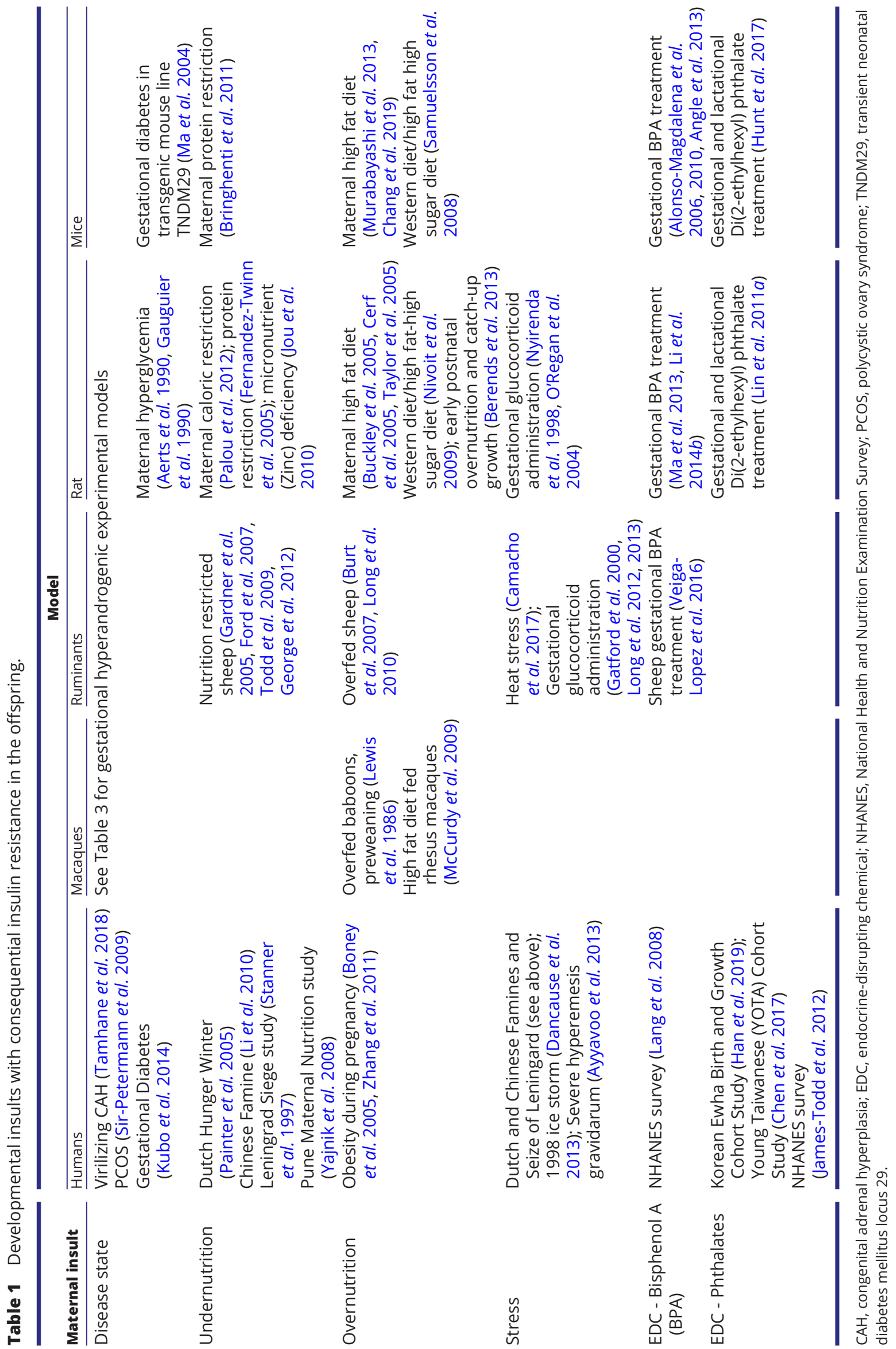


Table 2 Induction of hyperandrogenemic maternal hormone milieu by developmental insults.

\begin{tabular}{l}
\hline Maternal insult \\
\hline Disease state \\
- PCOS \\
- Virilizing CAH \\
- Pestational diabetes \\
Undernutrition \\
Overnutrition \\
Stress \\
EDC - Bisphenol A \\
EDC - Phthalates
\end{tabular}

Maternal androgen milieu

Sir-Petermann et al. 2002

Parsa and New 2017

Morisset et al. 2013

Acromite et al. 1999

Mossa et al. 2019

Whyte et al. 2007, Arnon et al. 2016, Maliqueo et al. 2017, Pasquali and Oriolo 2019

Barrett and Swan 2015

Takeuchi et al. 2004, Rutkowska and Rachon 2014

Sathyanarayana et al. 2017

$\mathrm{CAH}$, congenital adrenal hyperplasia; EDC, endocrine-disrupting chemical; PCOS, polycystic ovary syndrome.

(CYP19) expression in trophoblast cultures treated with BPA (Chu et al. 2018), reduced 3 $\beta$-hydroxysteroid dehydrogenase and CYP19 in the JEG 3 placental cell line treated with phthalate metabolites (Xu et al. 2016), and increased 7 $\alpha$-hydroxylase/17,20-lyase (CYP17) expression in ovarian cells exposed to BPA (Zhou et al. 2008). In addition, EDC-mediated disruption in hepatic steroid hormone metabolism could influence steroid bioavailability. EDCs have been shown to bind nuclear receptors such as the aryl hydrocarbon receptor $(\mathrm{AhR})$ and pregnane $\mathrm{X}$ receptor (PXR) and regulate the expression of hepatic enzymes that metabolize steroid hormones (Mikamo et al. 2003, Sanderson 2006, Tabb $\&$ Blumberg 2006). For example, AhR binding of PCB or dioxin upregulates expression of CYP1A1, CYP1A2, and CYP1B1 (Kohn et al. 1993, Wakui et al. 2006, Tarnow et al. 2019), while alkylphenols and DDT acting through PXR inhibit hepatic clearance of estradiol in rats (El-Hefnawy et al. 2017). Overall these data indicate the capacity for EDCs to act indirectly as well as directly to influence the maternal and fetal steroidal milieu and contribute to the programming of insulin resistance, a premise requiring further study.

Experimental animal models provide robust direct evidence in support of steroidal programming of insulin resistance (Table 3). For instance, gestational androgen treatment culminates in insulin resistance during adulthood in female offspring of rodents, sheep, and non-human primates (Roland et al. 2010, Abbott et al. 2016, Cardoso \& Padmanabhan 2019). In sheep, days 30-90 of gestation encompass the period of organization of metabolic systems (Padmanabhan \& Veiga-Lopez 2014). The main metabolic defects observed in adult sheep treated prenatally with testosterone from days 30 to 90 of gestation include peripheral insulin resistance with compensatory hyperinsulinemia and associated dyslipidemia, oxidative stress, and hepatic steatosis
(Padmanabhan et al. 2010b, Veiga-Lopez et al. 2013, Puttabyatappa \& Padmanabhan 2017). Similarly, animal models of gestational glucocorticoid administration have documented adverse fetal programming of the hypothalamic-pituitary-adrenal (HPA) axis and longterm effects during adulthood on cardiometabolic function (Moisiadis \& Matthews 2014, Constantinof et al. 2016). Gestational exposure to EDCs in various animal models also provide direct evidence for the role of steroidal disruption in programming insulin resistance. Such evidence is available for a wide range of EDCs, including BPA and phthalate metabolites (Strakovsky et al. 2015, Provvisiero et al. 2016, Veiga-Lopez et al. 2016). The developmental impact of protein restriction (a model of undernutrition) and high fat/western diet feeding (a model of overnutrition) have been studied in both rodents and nonhuman primates (Friedman 2015, Neri \& Edlow 2015, Ong \& Ozanne 2015, Nicholas et al. 2016). Although all these conditions are associated with offspring insulin resistance with coincident increases in maternal androgens (Table 2), androgen ablation studies are required to ascertain whether androgens are indeed the programmers of insulin resistance in these scenarios.

\section{Androgen programming of peripheral insulin resistance}

Peripheral insulin resistance is characterized by clinical findings of hyperglycemia, hyperinsulinemia, and impaired glucose tolerance. Evidence supportive of androgen programming of peripheral insulin resistance in the offspring comes from studies in mice, sheep, and rhesus macaques treated with testosterone during gestation (Roland et al. 2010, Abbott et al. 2016, Cardoso \& Padmanabhan 2019). Comparative studies of sheep treated prenatally with testosterone and dihydrotestosterone (DHT, a non-aromatizable and more https://joe.bioscientifica.com

https://doi.org/10.1530/JOE-20-0044
(C) 2020 Society for Endocrinology Published by Bioscientifica Ltd.
Printed in Great Britain 
Table 3 Developmental programming of insulin resistance by gestational androgen.

\begin{tabular}{|c|c|}
\hline \multicolumn{2}{|c|}{ Animal model } \\
\hline Species & Treatment \\
\hline Rhesus Macaques & $\begin{array}{l}\text { Testosterone GD } 40-80 \\
\text { (term 160) }\end{array}$ \\
\hline Rhesus Macaques & $\begin{array}{l}\text { Testosterone GD 100-115 } \\
\text { (term 164) }\end{array}$ \\
\hline Sheep (Suffolk) & $\begin{array}{l}\text { Testosterone GD 30-90 } \\
\text { (term 147) }\end{array}$ \\
\hline
\end{tabular}

Sheep (Suffolk)
Sheep (Suffolk)
Sheep (Scottish
Greyface x Texel)
Rat (Wistar)

DHT GD 30-90 (term 147) Yes

Testosterone GD 60-90 Yes (term 147)

Testosterone GD 62-102 Yes

(term 147)

Testosterone GD $20 \quad$ Yes

(term 21)

Rat (Wistar)

Testosterone GD 15-19 (term 21)

Rat (Sprague Dawley) Rat (Wistar)

DHT GD 16-19 (term 21) Testosterone (5.0 mg daily) No GD 16-19 (term 21)

Rat (Wistar)

DHT Day 21-111 postnatal Yes

Rat (Wistar)

Rat (Wistar)

Letrazole Day 21-111 postnatal

Estradiol Valerate Single No injection Day 56 postnatal

Rat (Sprague Dawley) DHEA Day 21-41 postnatal

Rat (Sprague Dawley)

Testosterone Day 28-48 postnatal

Mouse (C57BL/N6)

Letrazole Day 28-88 postnatal

Mouse (C57BI/6)

Mouse (C57BI/6])

DHT GD 16-18 (term 20)

DHT Day 21-111 postnatal

No

No

Mouse (C57BI/6J)

DHEA Day 21-111 postnatal No

Mouse (C57BI/6J)

Letrozole Day 21-111

No postnatal

Mouse (C57BI/6J)

Mouse (CBB6/F1)
DHT Day 19-109 postnatal Yes

DHT GD 16-18 (term 20) Yes nsulin

Remarks

Fetal: transient hyperglycemia and hyperinsulinemia (Abbott et al. 2010) Infants: increased basal insulin and beta cell number (Nicol et al. 2014) Adulthood: impaired disposition index, a measure of beta cell function and the ability to dispose glucose load (Eisner et al. 2000) Impaired glucose tolerance in adulthood (Eisner et al. 2000)

Juvenile period: decreased insulin sensitivity (Recabarren et al. 2005, Cardoso et al. 2016)

Prepubertal period: decreased (Padmanabhan et al. 2010a) or normal (Recabarren et al. 2005, Cardoso et al. 2016) insulin sensitivity based on proximity to puberty

Postpubertal/early adulthood: normal (Recabarren et al. 2005, Cardoso et al. 2016) or increased (Veiga-Lopez et al. 2013) insulin sensitivity Adulthood: Reduced insulin sensitivity (Padmanabhan et al. 2010b) Reduced insulin sensitivity at prepubertal age (Padmanabhan et al. 2010a)

Reduced insulin sensitivity in adulthood (Padmanabhan et al. 2010b)

Adult age: normal glucose homeostasis but elevated basal insulin levels (Hogg et al. 2011)

Single injection of testosterone during gestation impaired insulin sensitivity with normal HOMA index and glucose tolerance (Noroozzadeh et al. 2015)

Female offspring were insulin resistant compared male offspring, and this phenotype was prevented by flutamide or tamoxifen co-administration (Hu et al. 2015)

Insulin resistance observed at pubertal age (Yan et al. 2013)

Administration of $5 \mathrm{mg}$ testosterone daily did not affect insulin sensitivity, but animals developed lipid disturbances and hepatic steatosis (Sun et al. 2012)

Hyperglycemia and hyperinsulinemia with increased body weight and perirenal fat at the end of the treatment perioda (Yanes et al. 2011)

Decreased insulin sensitivity at the end of 90-day DHT treatment ${ }^{\mathrm{a}}$ (Mannerås et al. 2007)

No effect on insulin sensitivity at the end of 90-day DHT treatment (Mannerås et al. 2007)

No change in insulin sensitivity or androgen levels (Stener-Victorin et al. 2005)

Higher fasting glucose and insulina (Wang et al. 2004)

Hyperinsulinemia with reduced rate of glucose uptakea (Holmäng et al. 1990)

Impaired glucose tolerance at unspecified agea (Kauffman et al. 2015)

No effect on fasting glucose levels or insulin levels at 3 and 16 weeks of age (Caldwell et al. 2014)

No effect on fasting glucose levels or insulin levels at 16 weeks of age ${ }^{a}$ (Caldwell et al. 2014)

No effect on fasting glucose levels or insulin levels at 16 weeks of

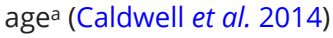

No effect on fasting glucose levels or insulin levels at 16 weeks of agea (Caldwell et al. 2014)

Glucose intolerant at the end of a 90-day DHT treatmenta (van Houten et al. 2012)

Prepuberty through adulthood: impaired glucose intolerance (Roland et al. 2010)

a Observations made either during treatment or end of treatment period - whether these effects are programmed or due to activational effects is not known.

DHT, dihydrotestosterone; GD, gestational days.

https://joe.bioscientifica.com

https://doi.org/10.1530/JOE-20-0044 (c) 2020 Society for Endocrinology Published by Bioscientifica Ltd. Printed in Great Britain 
active metabolite of testosterone) provide direct evidence that insulin resistance is programmed specifically through the androgenic actions of testosterone (Padmanabhan et al. 2010b). The involvement of androgens in the programming of insulin resistance is also supported by evidence of hyperinsulinemia during adolescence in daughters born to women with PCOS (Sir-Petermann et al. 2009) who have higher androgen levels during pregnancy (Sir-Petermann et al. 2002). The insulin resistance evident in offspring from pregnancies of women with CAH (Reisch et al. 2011), maternal disease states such as PCOS and gestational diabetes (Sir-Petermann et al. 2009, Bianco \& Josefson 2019), nutritional deficit/excess (Godfrey et al. 2017, Ong \& Guest 2018), stress (Moisiadis \& Matthews 2014, Facchi et al. 2019), and environmental EDC exposures (Gore et al. 2015, Veiga-Lopez et al. 2016, Sargis \& Simmons 2019) along with the evidence that these conditions induce increased maternal androgen levels (Table 2) (Takeuchi et al. 2004, Whyte et al. 2007, Rutkowska \& Rachon 2014, Barrett \& Swan 2015, Arnon et al. 2016, Maliqueo et al. 2017, Parsa \& New 2017, Sathyanarayana et al. 2017), point to androgens as a likely culprit in the programming of peripheral insulin resistance, a premise that needs to be formally tested using interventional strategies such as androgen antagonism.

\section{Androgen programming of tissue-specific insulin resistance}

Disruptions in both insulin-responsive tissues (liver, muscle, and adipose tissue) as well as in insulin-producing tissues (pancreas) collaborate in the development of systemic and tissue-level insulin resistance. Tissue effects of insulin involve ligand binding to the insulin receptor (IR) that triggers downstream signaling events, including phosphorylation of protein kinase B (AKT), mitogen-activated protein kinase/extracellular signal-regulated kinase (MAPK/ERK), and the mammalian target of rapamycin (mTOR) (Saltiel \& Kahn 2001, Guo 2014). Collectively, these signaling events promote glucose uptake as well as lipid and protein anabolic metabolism. Therefore, impairment at any level of the insulin signaling pathway may result in insulin resistance with consequential hyperglycemia (Rask-Madsen \& Kahn 2012). Evidence to date points to the role that developmental steroid exposures, especially androgens, play in programming tissue-specific insulin sensitivity. The following sections address the androgen programming of insulin sensitivity at metabolic targets, namely, liver, muscle, adipose tissue, pancreas, brain, and cardiac tissues.

\section{Liver}

Liver is a critical regulator of metabolic physiology, with insulin playing a central role in glucose, protein, and lipid metabolism. In the liver, insulin reduces blood glucose levels by inhibiting gluconeogenesis and glycogenolysis while promoting glycogen synthesis. Gluconeogenesis is inhibited by insulin-stimulated AKT-mediated phosphorylation of the transcription factor forkhead box protein O1 (FOXO1), which downregulates expression of gluconeogenic enzymes, including phosphoenolpyruvate carboxykinase (PEPCK) and glucose-6-phosphatase (G6Pase) (Guo 2014). Glycogen synthesis is stimulated through AKT-dependent phosphorylation and inhibition of glycogen synthase kinase-3 beta (GSK3B), which promotes the dephosphorylation and activation of glycogen synthase. AKT-dependent inhibition of tuberous sclerosis protein-2 (TSC2) consequently activates mTORC1 and ribosomal protein S6 kinase (S6K), which promote protein synthesis (Inoki et al. 2002) and stimulate transcription of sterol regulatory element-binding protein 1 (SREBP1), resulting in increased expression of lipogenic genes (Ruiz et al. 2014).

Studies addressing the programming of offspring hepatic insulin sensitivity by maternal disease state are not available in humans; however, data from animal models of developmental insults show defects at multiple levels of the insulin signaling pathway. For instance, both male and female offspring born to obese sheep manifest decreased protein abundance of IR, phosphorylated AKT, and phosphorylated FOXO1 (Nicholas et al. 2013). Similarly, male offspring of obese mice manifest decreased levels of insulin receptor substrate (IRS) 1, phosphorylated IRS1, and phosphorylated AKT as well as increased levels of GSK3B (Martin-Gronert et al. 2010). Hyperinsulinemia and hyperglycemia observed in male offspring born to pregnant rats treated with dexamethasone, a model of fetal exposure to excess glucocorticoids, is also accompanied by increased expression and activity of the gluconeogenic enzyme PEPCK, suggesting defects in hepatic insulin signaling (Drake et al. 2005). Gestational treatment with BPA in mice also reduced expression of Irs2, Akt2, G6pc, and Srebp1 in the liver of both male and female offspring (Van der Meer 2015). All of the above discussed maternal insults (obesity, stress, and EDC exposure) provide evidence in support of the hypothesis that gestational insults that program the development of hepatic insulin resistance and systemic hyperinsulinemia are also associated with increases in maternal androgens (Table 2) (Takeuchi et al. 2004, Whyte et al. 2007, Rutkowska \& Rachon 2014, Barrett \& Swan 2015, 
Arnon et al. 2016, Maliqueo et al. 2017). The commonality of androgen excess in these pathophysiological states suggests that androgens are a likely contributor to the programming of these metabolic defects. Importantly, the exact developmental changes observed after these programming events may vary depending on both the timing of the insult and the life period during which analyses are performed. For example, while gestational testosterone treatment induces higher mTOR protein level and greater phosphorylation of S6K and GSK3B in the livers of female fetal day 90 sheep suggesting an insulin sensitive state (Lu et al. 2016), IR2, IRS2, AKT, and $m T O R$ mRNA are downregulated in adult life (Nada et al. 2010) indicative of an insulin resistant hepatic phenotype. The reduced hepatic insulin sensitivity during adult life is supported by evidence of reduced phosphorylation of AKT under insulin-stimulated conditions in prenatally testosteronetreated female sheep (Lu et al. 2016). Co-treatment with an androgen antagonist prevented the fetal, but not the adult, changes in insulin signaling, indicating that the consequences of androgen programming during adult life may be subject to activational inputs and thus masked or unmasked by the prevailing adult hormone milieu. For example, increases in modulators of insulin sensitivity such as lipid accumulation in the liver leading to hepatic steatosis, inflammation, and oxidative stress during adult life of all animal models discussed above (McCurdy et al. 2009, Ashino et al. 2012, Lynch et al. 2017, Puttabyatappa et al. 2017, 2019b, Shimpi et al. 2017) may aid in maintaining the insulin resistant state programmed by gestational insults. Although hepatic lipid accumulation is also observed in offspring of gestationally DHT-treated mice, the mechanisms by which this develops and the disruptions in the insulin signaling cascade remains to be determined (Caldwell et al. 2014).

\section{Muscle}

Muscle is largely responsible for postprandial glucose disposal, with insulin promoting glucose uptake through AKT stimulation of GLUT4 protein translocation to the cell membrane (Dimitriadis et al. 2011). While disease states such as PCOS are associated with aberrant skeletal muscle gene expression and signaling pathways (Nilsson et al. 2018, Hansen et al. 2019, Shen et al. 2019, Stepto et al. 2019), generational studies addressing developmental insults in androgen programming of muscle-specific insulin signaling disruptions is lacking in humans. However, in animal models of maternal obesity, which show increased maternal androgen levels (Whyte et al. 2007, Arnon et al. 2016, Maliqueo et al. 2017,
Pasquali \& Oriolo 2019) and offspring insulin resistance, muscle-specific disruptions in insulin signaling and GLUT4 levels are evident. One study of male offspring born to obese pregnant rats found reduced levels of skeletal muscle Glut4 expression (Simar et al. 2012), while another study in rat offspring (of unspecified sex) had reduced expression of Ir and Glut4 in muscle (Bayol et al. 2005). In sheep models of maternal obesity, insulin resistance in the offspring is associated with reduced expression of insulin signaling intermediates when both male and female offspring were assessed together (Yan et al. 2010). Similarly, female mice born to obese dams exhibited reduced IRS1 and PI3K protein levels as well as decreased AKT phosphorylation at serine residue 473 (i.e. site of activation by insulin) in the skeletal muscle (Shelley et al. 2009). The associated increased levels of maternal androgens during pregnancy that occur in both mice and humans with obesity (Whyte et al. 2007, Arnon et al. 2016, Maliqueo et al. 2017, Pasquali \& Oriolo 2019) suggest that androgens may be involved in the programming of offspring muscle insulin resistance in the context of maternal obesity. Studies of gestationally testosterone-treated sheep support this premise with the observation of decreased phosphorylated-GSK3B and GLUT4 protein levels in female fetuses at fetal day 90 and impaired insulin stimulation of AKT phosphorylation in adult female offspring (Lu et al. 2016). Although GLUT4 levels have not been examined during adulthood, the reduced AKT phosphorylation is likely to result in reduced GLUT4 membrane translocation in adult sheep as well, likely resulting in increased glucose levels.

\section{Adipose}

As in muscle, adipose tissue glucose uptake is primarily driven by insulin; however, because adipose tissue accounts for only $5-10 \%$ of whole body glucose uptake, it has only a minor role in postprandial glucose regulation (Dimitriadis et al. 2011). Despite this fact, adipose tissue influences the insulin sensitivity of other tissues through release of free fatty acids and adipokines (Rosen \& Spiegelman 2006, Tchernof \& Despres 2013); as such, increased adiposity and adipose dysfunction are major risk factors for the development of insulin resistance (Kahn $\&$ Flier 2000). Because of this role of adipose tissue, the majority of studies examining adipose programming by developmental insults such as maternal obesity is focused on the assessment of adipose tissue phenotype.

The hyperandrogenic state of PCOS likely contributes to the insulin resistance in the absence or presence of obesity (Dumesic et al. 2007). Importantly, the daughters 
born to mothers with PCOS also manifest insulin resistance (Sir-Petermann et al. 2009), suggesting that the maternal hyperandrogenic state of PCOS may contribute to the developmental programming of insulin resistance across generations. At the level of adipose tissue, several studies in women with PCOS, mostly conducted on subcutaneous adipose tissue (SAT), have found adipose tissue to be insulin resistant (Cree-Green et al. 2015, 2017, Dumesic et al. 2019); other studies have found adipose to be more insulin sensitive (Corbould \& Dunaif 2007, Ciaraldi et al. 2009). In studies demonstrating adipose insulin resistance, disruptions are evident at multiple levels of insulin signaling, including: (1) a rightward shift in the insulin dose-response curve for insulin-stimulated glucose uptake in isolated adipocytes (Ciaraldi et al. 1992); (2) reduced phosphorylation of IRS1 and IRS2 (Qiu et al. 2005, Wang et al. 2005); (3) hyperactivation of GSK3B that is resistant to insulin-stimulated downregulation (Chang et al. 2008); and (4) decreased expression of GLUT4 (Rosenbaum et al. 1993). These findings are supportive of androgens gestationally programming adipose insulin resistance. Considering that the majority of women with PCOS are also obese, the increased adiposity per se may further amplify the programmed insulin sensitivity defects induced by androgen excess. This premise is supported by several observations, including: (1) treatment of female rhesus macaques with testosterone from menarche (a developmental programming window) coupled with a Western diet leads to greater insulin resistance than that observed in either the testosterone-treated or Western diet-fed conditions alone (True et al. 2017); and (2) gestational testosterone treatment coupled with postnatal obesity in female sheep leads to earlier impairments in insulin sensitivity compared to offspring only exposed to testosterone (Padmanabhan et al. 2010b). Interestingly, gestational testosterone treatment promoted preferential accumulation of metabolically deleterious visceral adipose tissue (VAT) in female rhesus macaques (Eisner et al. 2003), indicating that the steroidal programming of metabolism includes disruption of adipocyte insulin signaling and adipose mass and distribution. Male offspring from dams gestationally stressed by diet-induced obesity in mice (Fernandez-Twinn et al. 2014) and caloric-restricted rats (Berends et al. 2013) manifest insulin resistance and impaired adipose insulin signaling characterized by reduced levels of Ir2, Irs1, phosphatidylinositol-3-kinases (Pi3k), and Akt. Associated increases in maternal androgen levels in these models (Table 2) (Maliqueo et al. 2017, Mossa et al. 2019) suggest that programming of insulin resistance in adipose tissue may be androgen dependent.
In stark contrast, a lack of change in the phosphorylation states of AKT, mTOR, ERK, GSK3B, and S6K during fetal life as well as increased mRNA expression of IR2, mTOR, $A K T, P I 3 K$, and peroxisome proliferator-activated receptor gamma (PPAR $\gamma)$ in the VAT with increased insulinstimulated phosphorylated-AKT in the VAT and SAT in adult female offspring of gestationally testosterone-treated sheep (Nada et al. 2010, Lu et al. 2016) reflect an insulinsensitive state in adipose tissue. Whether these differences in adipose insulin sensitivity programmed by gestational insults is due to differences in the adipose depot examined, species- or sex-specific differences, developmental time point studied, or differences in adipocyte differentiation (adipocyte hypertrophy in PCOS and offspring of obese mice (Manneras-Holm et al. 2011, Caldwell et al. 2014, Ibanez et al. 2018) vs adipocyte hypotrophy in gestational testosterone-treated sheep (Cardoso et al. 2016)) requires further examination.

\section{Pancreas}

As insulin resistance is often accompanied by compensatory increases in insulin secretion, impairment in pancreatic beta-cells can contribute to compromised insulin sensitivity, potentially through inappropriate insulin secretion (Shanik et al. 2008). In pregnant women hyperandrogenemia during pregnancy (Gozukara et al. 2015) is associated with the development of gestational diabetes leading to the development of insulin resistance in the offspring (Bianco \& Josefson 2019), disruptions in beta-cell function and development of compensatory hyperinsulinemia (Singh et al. 2006, Kelstrup et al. 2013). Similarly, in rat models of maternal high fat feeding, male offspring have disrupted beta-cell gene expression characteristic of impaired function (Agarwal et al. 2019) and impaired insulin signaling (e.g. reduced IRS1 and $A K T$ with increased FOXO1 expression) (Bringhenti et al. 2016). As high-fat diet-fed dams exhibit hyperandrogenemia during gestation (Whyte et al. 2007, Arnon et al. 2016, Maliqueo et al. 2017), androgens may program betacell disruptions in the offspring. The identification of pancreatic beta-cell defects with associated elevations in basal insulin secretion in female fetuses born to gestationally testosterone-treated sheep support such a notion (Rae et al. 2013). Another study of testosterone administration at gestational days 62 and 82 showed that female fetuses had increased beta-cell numbers at both fetal and adolescent ages with elevated basal insulin secretion (Ramaswamy et al. 2016), suggesting androgen programming of beta-cell dysfunction that leads to hyperinsulinemia. The observation that this phenotype 
was evident only in animals that received testosterone and not diethylstilbestrol or dexamethasone during gestation imply specific involvement of androgens in the steroidal programming of beta-cell dysfunction (Ramaswamy et al. 2016).

\section{Heart}

Cardiac tissue uses free fatty acids as its primary source of energy; however, it also utilizes glucose during fetal life and periods of stress (Abel 2004). As in skeletal muscle, insulin influences glucose uptake and storage in the myocardium. Maternal weight gain and obesity are associated with the development of cardiovascular defects (Gaillard 2015). In sheep models of maternal obesity, offspring manifest hyperinsulinemia with increased activation of AKT, ERK, and mTOR in cardiac tissues with cardiac hypertrophy (Fernandez-Twinn et al. 2012). As gestational obesity is associated with increases in maternal androgens (Table 2) (Whyte et al. 2007, Arnon et al. 2016, Maliqueo et al. 2017), these cardiac changes may be programmed by androgens. In support of this, gestationally testosterone-treated sheep also exhibit elevated expression of $m T O R C 1$ and increased phosphorylation of PI3K, AKT, and mTOR with associated cardiac hypertrophy (Vyas et al. 2016).

\section{Brain}

The function of insulin in the brain is not confined to regulation of glucose availability from the periphery. Insulin influences neuronal function, and disruptions in brain insulin action is thought to be a basis for neurodegenerative and mood disorders as well as the metabolic syndrome (Kleinridders et al. 2014). In addition, there is crosstalk between insulin and appetite regulators, including orexigens such as neuropeptide $\mathrm{Y}$ (NPY) and anorexigens such as proopiomelanocortin (POMC) (Breton 2013, Vogt \& Bruning 2013), which influence systemic tissue-level insulin sensitivity. Gestational insults that program peripheral insulin resistance (e.g. diet-induced maternal obesity) also induce insulin resistance in the male rat hippocampus with reduced levels of Ir2, Pi3k, and Akt levels (Gomes et al. 2018). Similar changes have also been observed in female offspring of gestationally testosterone-treated sheep with reduced IR2 levels in the hypothalamic arcuate nucleus, an effect that was reversed with gestational androgen antagonist treatment (Cernea et al. 2016). These data coupled with the fact that maternal androgens are elevated in animal models of dietinduced obesity (Whyte et al. 2007, Arnon et al. 2016,
Maliqueo et al. 2017) indicate that insulin resistance in these neurons may be programmed by androgens. Surprisingly, male offspring of gestationally estradioltreated mice had decreased hypothalamic IR mRNA and protein expression associated with the development of insulin resistance (Wang et al. 2018), indicating the potential for estrogenic mediation of insulin resistance as well. However, the finding that androgen receptor antagonists reversed the decrease in IR expression in the hypothalamic arcuate nucleus in prenatal testosterone-treated sheep effectively rules out estrogen as the mediator in this model and point to androgens as the culprits.

\section{Mediators of androgen programming of insulin resistance}

Steroid hormones elicit their actions through direct actions and via intermediaries to reorganize pathways involved in insulin production and function. Direct actions may involve signaling through their nuclear or membrane receptors with consequential alterations in gene transcription and signal transduction that regulate metabolic functions (Faulds et al. 2012). Indirect actions may be facilitated via alterations in the inflammatory, oxidative, or lipotoxic state as well as through the involvement of epigenetic modifications. More recently, the role of the gut microbiome in the developmental programming and pathogenesis of insulin resistance has also been suggested.

\section{Inflammation}

Inflammation is a complex process that involves the production of cytokines and other inflammatory mediators as well as the activation and invasion of immune cells; these effects are associated with the metabolic dysfunction associated with obesity and T2DM (Esser et al. 2014). While physiological inflammatory modulation of processes regulated by adrenocortical steroids are involved in the processes of lung maturation and parturition (Keelan 2018) as well as in the sex steroid programming of behavioral sexual dimorphism (McCarthy et al. 2017), maternal disease states (e.g. gestational diabetes (Pantham et al. 2015), preeclampsia (Gomez-Lopez et al. 2019, Tenorio et al. 2019), maternal stress, obesity, and exposure to EDCs) that lead to the development of offspring insulin resistance (Godfrey et al. 2017, Facchi et al. 2019, Sargis \& Simmons 2019) are also associated with pathophysiological maternal 
inflammation (Schmatz et al. 2010, Ingvorsen et al. 2015, Ozias et al. 2015, Alfaradhi et al. 2016, Dewi et al. 2017, Dudele et al. 2017, Bansal et al. 2018, Gu et al. 2018, Zota et al. 2018, Desplats et al. 2019, Kelley et al. 2019a, Song et al. 2020) and an altered androgen milieu (Table 2) (Acromite et al. 1999, Takeuchi et al. 2004, Whyte et al. 2007, Morisset et al. 2013, Rutkowska \& Rachon 2014, Vejrazkova et al. 2014, Barrett \& Swan 2015, Arnon et al. 2016, Maliqueo et al. 2017, Sathyanarayana et al. 2017) in both humans and animals. These findings implicate androgens and inflammatory processes in the programming of insulin resistance. Strong associations exist between inflammatory biomarkers and cortisol in mothers with major depressive disorder (Osborne et al. 2018) as well as placental inflammation following maternal exposure to BPA in the sheep (Song et al. 2020). As these states are associated with an increased androgenic maternal milieu (Takeuchi et al. 2004, Rutkowska \& Rachon 2014, Barrett \& Swan 2015), it is possible that inflammatory state in these situations also involve androgens. The finding that gestational treatment with testosterone leads to placental inflammation in sheep (Kelley et al. 2019b), and the female offspring of these animals develop insulin resistance (Padmanabhan et al. 2010b) lend support to the possibility that gestational androgen-mediated programming of offspring insulin resistance may involve inflammatory pathways. Further studies are needed to establish the absolute contribution of inflammatory processes to programmed metabolic dysfunction and to determine if inflammation is the key mediator of the androgenic programming of insulin resistance.

\section{Oxidative stress}

Physiological levels of reactive oxygen species (ROS) aid in placentation and fetal development by virtue of their role in cell signaling and gene transcription. However, breakdown of antioxidant defense mechanisms and accumulation of ROS lead to oxidative stress (Lushchak 2014), with consequential damage to cellular components, including proteins, lipids, DNA, and cellular organelles (Valko et al. 2007). Developmental stress arising from maternal disease states (Zhu et al. 2015, Tenorio et al. 2019), maternal obesity (Valko et al. 2007), and stress (Lorigooini et al. 2019, Venkatesh et al. 2019), as well as from environmental chemical exposures (Ferguson et al. 2014, Neier et al. 2015, Veiga-Lopez et al. 2015, Watkins et al. 2015, Puttabyatappa et al. 2019a) are associated with maternal oxidative stress (Luo et al. 2006, Valko et al. 2007), a known contributor to the developmental origins of insulin resistance (Thompson \& Al-Hasan 2012, Rodriguez-Rodriguez et al. 2018). Because these conditions are also associated with changes in the maternal androgen milieu (Table 2) (Acromite et al. 1999, Sir-Petermann et al. 2002, Takeuchi et al. 2004, Whyte et al. 2007, Morisset et al. 2013, Rutkowska \& Rachon 2014, Barrett \& Swan 2015, Arnon et al. 2016, Maliqueo et al. 2017, Sathyanarayana et al. 2017), the fetal programming of insulin resistance likely involve crosstalk between androgen signaling and oxidative stress pathways. Evidence for involvement of oxidative stress in the androgen programming of insulin resistance also comes from strong associations between steroid hormone-disrupting EDCs (e.g. phenols, parabens, and phthalate metabolites) and maternal and fetal oxidative stress in epidemiologic studies (Ferguson et al. 2014, Veiga-Lopez et al. 2015, Watkins et al. 2015, Puttabyatappa et al. 2019a) along with the induction of offspring insulin resistance after gestational exposure to these same EDCs in animal models (Angle et al. 2013, Rajesh \& Balasubramanian 2014, Veiga-Lopez et al. 2016). Apart from their steroid potential, EDCs such as BPA and phthalates are also associated with increases in maternal androgen levels (Takeuchi et al. 2004, Rutkowska \& Rachon 2014, Sathyanarayana et al. 2017) implicating androgens as potential mediators in inducing a prooxidant state. Other studies have shown that high-fat diet induces obesity (Hariri \& Thibault 2010), placental oxidative stress (Lin et al. 2011b), and insulin resistance in offspring (Matsuzawa-Nagata et al. 2008) and antioxidant supplementation during pregnancy ameliorates hyperinsulinemia in offspring (Sen \& Simmons 2010). These findings suggest a direct involvement of maternal oxidative stress in the programming of offspring insulin resistance. Since maternal obesity is associated with increases in maternal androgen levels (Whyte et al. 2007, Arnon et al. 2016, Maliqueo et al. 2017), androgens may be involved in increasing the oxidative stress. This premise is supported by the observation that gestational exposure to testosterone in sheep leads to increases in placental oxidative stress (Kelley et al. 2019b) and induction of insulin resistance in the female offspring (Padmanabhan et al. 2010b). However, key questions remain regarding the relative contribution of androgen excess and oxidative stress and their interactions in the programming of offspring insulin resistance.

\section{Lipotoxicity}

Excess accumulation of triglycerides in non-adipose tissues results in both acute and chronic cellular dysfunction, 
a process termed lipotoxicity (Weinberg 2006). These effects may be due either to direct lipotoxic effects or indirect induction of inflammation and oxidative stress as a result of lipid peroxide production. Observations in women with gestational diabetes and obesity as well as in animal models mimicking these conditions show increased maternal, placental, and fetal lipid accumulation (Diamant et al. 1982, McCurdy et al. 2009, Li et al. 2011, Dong et al. 2013, Visiedo et al. 2013, Pruis et al. 2014, Saben et al. 2014, Jeve et al. 2015). Since these conditions also result in offspring insulin resistance (Matsuzawa-Nagata et al. 2008, Bianco \& Josefson 2019), lipotoxicity may be a contributing factor in the developmental programming of insulin action. Since these maternal conditions are also associated with increased maternal androgens (Table 2) (Whyte et al. 2007, Morisset et al. 2013, Arnon et al. 2016, Maliqueo et al. 2017), androgens may also play a role in the development of lipotoxicity. The observation in sheep models that gestational testosterone treatment increases placental lipid accumulation (Kelley et al. 2019b) supports such a possibility. Similar increases in placental lipotoxicity are also observed in sheep models of gestational BPA treatment (Song et al. 2020). As BPA exposure during pregnancy can increase maternal androgens (Takeuchi et al. 2004, Rutkowska \& Rachon 2014) and are known to induce insulin resistance (Veiga-Lopez et al. 2016), maternal androgens might contribute to development of later-life insulin resistance through lipotoxicity.

\section{Epigenetics}

Another mechanism by which steroids program metabolic pathways in offspring involves epigenetic alterations. Epigenetic changes include changes in DNA methylation, histone modifications, and expression of noncoding RNAs, all of which can lead to alterations in gene expression. Considering steroids are known to modulate developmentally programmed epigenetic changes (Forger 2018), androgen-induced epigenetic modifications of genes involved in insulin action in insulin target tissues or insulin production from pancreatic beta-cells are likely contributors to the developmental origins of insulin resistance (Sharma et al. 2017, Ebrahimi et al. 2019, Kerr et al. 2019).

Epigenetic modulation via DNA methylation involves addition of a methyl group to cytosines by DNA methyltransferases (DNMTs), resulting in changes in gene transcription (Ciccarone et al. 2018). DNA methylation is involved in the developmental programming of insulin resistance (Davegardh et al. 2018, Zhou et al. 2018), including in conditions associated with maternal disease states (Elliott et al. 2019, Kamrani et al. 2019), obesity (Fernandez-Twinn et al. 2019), stress (Cao-Lei et al. 2016), and following exposure to EDCs (Stel \& Legler 2015, Rahmani et al. 2018). Additional support comes from observations of (1) DNA methylation of hepatic genes involved in insulin and glucocorticoid receptor signaling in mice with fetal exposure to glucocorticoids under conditions of maternal food restriction (Ogawa et al. 2014); (2) the strong association that exists between gestational BPA levels and genome-wide DNA methylation and transcriptome changes in human fetal liver (Faulk et al. 2015); and (3) hypermethylation of DNA in the pancreas and liver of offspring from gestationally BPA-treated mice and rats, respectively (Rajesh \& Balasubramanian 2014, Bansal et al. 2017). Because all of these conditions are also associated with increases in maternal androgen levels (Table 2) (Sir-Petermann et al. 2002, Takeuchi et al. 2004, Whyte et al. 2007, Morisset et al. 2013, Rutkowska \& Rachon 2014, Barrett \& Swan 2015, Arnon et al. 2016, Maliqueo et al. 2017), the possibility exists that DNA methylation changes underlying the programming of insulin resistance in these scenarios may be a consequence of increased maternal androgens. Confirmation of the involvement of androgen-mediated DNA methylation in the programming of insulin resistance requires ablation studies with androgen antagonists and prevention of DNA methylation changes via maternal folic acid supplementation (Ly et al. 2016).

Epigenetic regulation through histone modifications includes acetylation, methylation, ubiquitination, phosphorylation, and sumoylation, all of which affect transcriptional activity through modification of the structure and conformation of chromatin and/or by the differential recruitment of transcriptional co-repressors or co-activators (Bannister \& Kouzarides 2011). Histone alterations are brought about by enzymes that include 'writers' such as histone acetyltransferases (HATs) and histone methyltransferases (HMTs) that modify histones as well as 'erasers' such as histone deacetylases (HDACs) and lysine demethylases (KDMs) that remove these modifications (Hyun et al. 2017). The impact of developmental insults on the programming of insulin resistance through histone modifications is understudied (Vaiserman \& Lushchak 2019). Evidence of a possible role of steroid-mediated histone modifications in fetal programming comes from the reprogramming of stress responses by fetal glucocorticoid exposures that induce transcriptional changes of genes involved in hypothalamic-pituitary-adrenal axis function through 
histone modifications (Dirven et al. 2017). Altered expression of the pancreatic beta-cell differentiation gene PDX1 in gestationally protein-restricted and BPAtreated rats (Park et al. 2008, Chang et al. 2016) as well as altered hepatic gene expression in gestationally high-fat diet-fed macaques and BPA-treated mice (Aagaard-Tillery et al. 2008, Strakovsky et al. 2015) are both associated with histone modifications. Of interest, these gestational manipulations lead to increases in maternal androgen levels (Takeuchi et al. 2004, Whyte et al. 2007, Rutkowska \& Rachon 2014, Barrett \& Swan 2015, Arnon et al. 2016, Maliqueo et al. 2017) and offspring insulin resistance (Rinaudo \& Wang 2012). Gestational testosterone treatment in sheep also increased expression of PDX1 in female fetuses (Rae et al. 2013), lending support to the possibility that androgen programming of insulin homeostasis may occur via histone modifications, a premise that needs formal testing.

The epigenetic regulation of insulin resistance may also be mediated via changes in noncoding RNAs (Desai et al. 2015, De Rosa et al. 2018), which include microRNAs (miRNAs), short ( 18-25 nucleotide), long (exceeding 200 nucleotides), and circular RNAs, of which miRNAs are the best studied. The evidence that steroidal programming involves miRNAs comes from sexual differentiation of neonatal mice brain (Morgan \& Bale 2017). The role of miRNAs in androgen programming of insulin resistance is supported by observations that miRNA expression is increased after maternal insults that promote an androgenic maternal hormone milieu (Table 2) and program insulin resistance, such as maternal disease states (Poirier et al. 2017, Hemmatzadeh et al. 2020), diet-induced obesity (Benatti et al. 2014, Mendez-Mancilla et al. 2018, Puppala et al. 2018), growth restriction (Zheng et al. 2017, Hromadnikova et al. 2019), stress (Cao-Lei et al. 2016, Wu et al. 2016), and BPA exposure (Lin et al. 2017, Martinez-Ibarra et al. 2019) in both humans and animal models. The observation that gestational testosterone treatment increases expression of miRNAs that target insulin signaling, albeit in fetal ovaries (Luense et al. 2011), along with findings that their offspring develop insulin resistance during adulthood (Padmanabhan et al. 2010b), raise the possibility that reprogramming of insulin resistance by androgens may also involve changes in expression of miRNA associated with insulin signaling genes in metabolic tissues.

\section{Microbiome}

The identification of bacteria and/or their DNA in amniotic fluid, fetal membranes, umbilical cord blood,

(C) 2020 Society for Endocrinology Published by Bioscientifica Ltd. Printed in Great Britain placenta, and meconium indicate that gut colonization begins during in utero life (Li et al. 2014a). Gut microbiota are required for host metabolism and fetal development, while reduced microbial diversity and dysbiosis is associated with gastrointestinal and systemic disorders, including obesity and insulin resistance (Wang et al. 2016). This is confirmed by studies in germ-free animals that consume more calories, become overweight, and exhibit insulin resistance and dyslipidemia (Laugerette et al. 2011). This association of dysbiosis with the development of insulin resistance (Wang et al. 2016, Codagnone et al. 2019) coupled with the observation that infants born to mothers with obesity or stress have altered gut microbiota (Collado et al. 2010, Zijlmans et al. 2015, Codagnone et al. 2019) and increased maternal androgens (Table 2) with consequential programing of offspring insulin resistance collectively suggest the potential for steroidal programming of insulin resistance through alterations in the microbiome. Although the influence of steroids on the gut microbiota have been explored (Huang et al. 2015, Tetel et al. 2018), the role of the microbiome in androgen programming is not established. There is evidence that gestational exposure to stress in mice (Gur et al. 2017), treatment of pregnant rats with the native steroid testosterone (Gur et al. 2017), or exposure of pregnant mice to EDCs such as BPA or synthetic estrogens (Javurek et al. 2016) all lead to altered gut microbiota. Since these gestational insults are associated with increased maternal androgens (Table 2 ) and can program insulin resistance, it is possible that androgen-induced gut microbial changes may be involved in androgen reprogramming of insulin responsiveness and development of insulin resistance. The finding that transplantation of gut microbiota from woman with PCOS into mice resulted in insulin resistance (Qi et al. 2019) indicates that further studies using fecal microbiota transplantation can be used to assess the relative contribution of gut microbiota in androgen programming of insulin resistance.

\section{Insulin}

An intriguing hypothesis set forth by published data and evident in clinical practice is the capacity of insulin to drive the development of insulin resistance (Gavin et al. 1974, Rizza et al. 1985, Shanik et al. 2008, Erion \& Corkey 2017). In the context of developmental programming, it is interesting to note that gestational hyperinsulinemia observed in gestational diabetes mellitus and obesity are associated with the development of insulin resistanceassociated conditions in the offspring later in life 
(Bellamy et al. 2009, Ruchat et al. 2013, Nicholas et al. 2016). Importantly, a major hormonal change associated with increased maternal androgens is hyperinsulinemia as androgen-mediated increases in insulin levels during pregnancy is evident in hyperandrogenic pregnant women with PCOS (Radon et al. 1999, Sir-Petermann et al. 2007) and pregnant sheep treated with testosterone (Abi Salloum et al. 2015). As such, programming of offspring insulin resistance by gestational testosterone excess may be mediated via increased levels of insulin itself. Indeed, since multiple conditions are also associated with increase in maternal androgens (Table 2) (Whyte et al. 2007, Morisset et al. 2013, Arnon et al. 2016, Maliqueo et al. 2017), the possibility androgen-mediated increases in maternal insulin levels contribute to programming of insulin resistance cannot be excluded. Moreover, it is interesting to speculate how such a scenario could establish a potential positive feedback loop in which persistent or even transient androgen excess increases insulin levels that then increase insulin resistance prompting further insulin release and potentiation of the effect. Intriguingly, insulin's potential role as a mediator of androgen-induced insulin resistance is supported by evidence that the metabolic disruptions observed in prenatally testosteronetreated sheep can be ameliorated by co-treatment with an insulin sensitizer (Puttabyatappa et al. 2017). Importantly, while suggesting a potential route by which androgens induce insulin resistance, such a mechanism would also provide support for potential interventions, including insulin sensitizers as well as exercise.

\section{Conclusions and future directions}

The 'thrifty phenotype hypothesis' proposed by Hales and Barker first explained how malnutrition during pregnancy leads to poor fetal growth and the programming of maladaptive metabolic responses in the developing fetus (Barker 2005). One of the key metabolic reprogramming events is the establishment of insulin responsiveness,

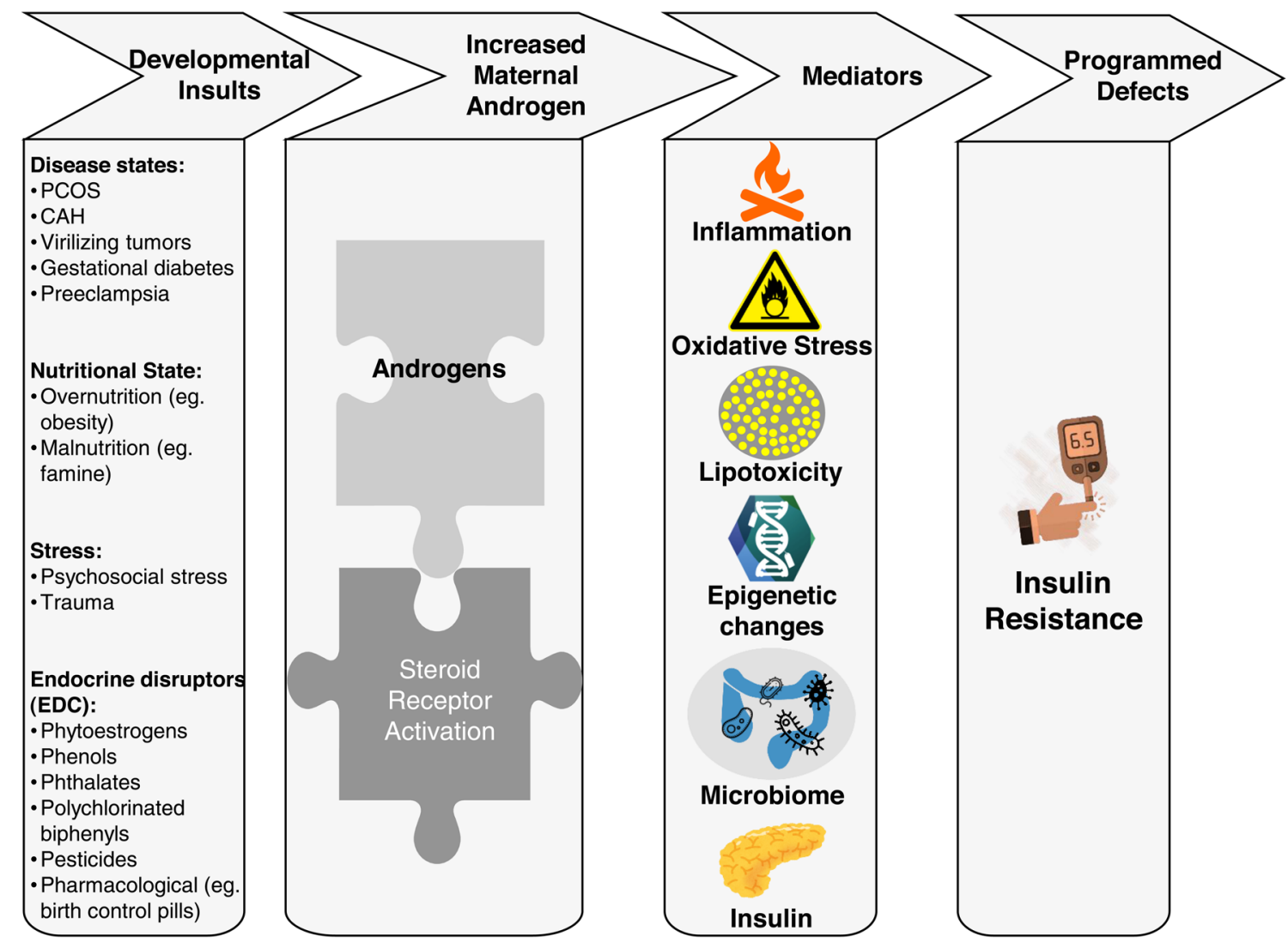

Figure 1

Schematic showing the potential link between developmental insults and increase in maternal androgen levels that program the onset of insulin resistance in the offspring. The increase in maternal androgens probably utilizes various mediators including changes in inflammatory state, oxidative stress, lipotoxicity, epigenetic, gut microbiome and insulin to bring about metabolic reprogramming leading to development of insulin resistance. Images used were sourced from open-source resources: www.pixabay.com, www.openclipart.org, and www.cleanpng.com. 
which leads to the development of insulin resistance. Since then this hypothesis has evolved into the DOHaD hypothesis, which captures the impact of wide ranging insults occurring during critical in utero and postnatal developmental windows on the reprogramming of metabolic functions. Critically, the mechanisms by which these developmental insults program later-life insulin resistance are still unresolved. As discussed above, a commonality among the various insults promoting insulin resistance (e.g. maternal disease states, stress, over/undernutrition, lifestyle, and exposure to EDCs) is alterations in the maternal steroid hormone milieu with specific increases in androgen levels (Fig. 1 and Table 2) (Takeuchi et al. 2004, Whyte et al. 2007, Rutkowska \& Rachon 2014, Barrett \& Swan 2015, Arnon et al. 2016, Maliqueo et al. 2017). Since steroids, and especially androgens, play a major role in establishing the program of sexual differentiation at both the gonadal and brain levels, exposure to excess androgens during critical periods of organization of metabolic functions may also influence the programming of metabolic tissues, potentially resulting in maladaptive changes that manifest as adult onset metabolic dysfunction, including insulin resistance. Human observations of insulin resistance among offspring born to mothers with high testosterone levels during pregnancy (e.g. women with PCOS) (Sir-Petermann et al. 2009) as well as in animal models of gestational treatment with androgens (Table 3) (Roland et al. 2010, Abbott et al. 2016, Cardoso \& Padmanabhan 2019) support this conjecture. Despite this evidence, however, further studies are needed to confirm the relative contribution of androgens in programming insulin resistance due to other maternal insults through the use of specific androgen receptor antagonists or other molecular approaches.

Another key observation arising from this discussion is that many of the studies conducted thus far have been confined to one sex of the offspring. Studies using rodent models have also grouped both sexes together to interpret findings. As it is now established that developmental insults have sex-specific effects (Dearden et al. 2018), future studies in both humans and animal models are required to be performed in both sexes. As sexual dimorphism is also apparent in placental function (Kalisch-Smith et al. 2017), studying the sexbased differences in this key mediator of maternalfetal transport are also required. Another challenge to consider is the sensitivity of specific developmental periods to respective in utero or postnatal insults since the same exposure at different times during prenatal life can lead to a wide spectrum of effects (Selevan et al.
2000). Additionally, as studies in animal models allow longitudinal and direct assessment of relevant target tissues to empower investigation of potential inter- and trans-generational transfer of traits, the comparability of the most sensitive window(s) for exposures in animal models are essential to provide comparison data across species, which in turn will identify those critical windows of vulnerability to be targeted for policy development and risk management. Considering pregnancies associated with hyperandrogenic state such as PCOS, preeclampsia, obesity, and stress are common in clinical practice, the establishment of androgens as mediators driving adverse metabolic programming in offspring will aid in the development of targeted clinical interventions to overcome the long-term effects of developmental insults that drive insulin resistance by restoring and supporting a normal maternal steroid milieu. Developing such interventions may hold immense potential for addressing the early-life origins of metabolic dysfunction that are epidemic across the globe.

\section{Declaration of interest}

The authors declare that there is no conflict of interest that could be perceived as prejudicing the impartiality of this review.

\section{Funding}

This work was supported by NIH: P01 HD44232 and P30 ES017885 (V P) and P30 ES027792 (R M S). M P's effort was supported by Ruth L. Kirschstein Institutional Training Grant T32 ES007062.

\section{References}

Aagaard-Tillery KM, Grove K, Bishop J, Ke X, Fu Q, Mcknight R \& Lane RH 2008 Developmental origins of disease and determinants of chromatin structure: maternal diet modifies the primate fetal epigenome. Journal of Molecular Endocrinology 41 91-102. (https://doi. org/10.1677/JME-08-0025)

Abbott DH, Bruns CR, Barnett DK, Dunaif A, Goodfriend TL, Dumesic DA \& Tarantal AF 2010 Experimentally induced gestational androgen excess disrupts glucoregulation in rhesus monkey dams and their female offspring. American Journal of Physiology: Endocrinology and Metabolism 299 E741-E751. (https://doi.org/10.1152/ ajpendo.00058.2010)

Abbott DH, Levine JE \& Dumesic DA 2016 Translational insight into polycystic ovary syndrome (PCOS) from female monkeys with PCOSlike traits. Current Pharmaceutical Design 22 5625-5633. (https://doi. org/10.2174/1381612822666160715133437)

Abel ED 2004 Glucose transport in the heart. Frontiers in Bioscience 9 201-215. (https://doi.org/10.2741/1216)

Abi Salloum B, Veiga-Lopez A, Abbott DH, Burant CF \& Padmanabhan V 2015 Developmental programming: exposure to testosterone excess disrupts steroidal and metabolic environment in pregnant sheep. Endocrinology 156 2323-2337. (https://doi.org/10.1210/en.2014-2006) 
Acromite MT, Mantzoros CS, Leach RE, Hurwitz J \& Dorey LG 1999 Androgens in preeclampsia. American Journal of Obstetrics and Gynecology 180 60-63. (https://doi.org/10.1016/s00029378(99)70150-x)

Aerts L, Holemans K \& Van Assche FA 1990 Maternal diabetes during pregnancy: consequences for the offspring. Diabetes/Metabolism Reviews 6 147-167. (https://doi.org/10.1002/dmr.5610060303)

Agarwal P, Brar N, Morriseau TS, Kereliuk SM, Fonseca MA, Cole LK, Jha A, Xiang B, Hunt KL, Seshadri N, et al. 2019 Gestational diabetes adversely affects pancreatic islet architecture and function in the male rat offspring. Endocrinology 160 1907-1925. (https://doi.org/10.1210/ en.2019-00232)

Alfaradhi MZ, Kusinski LC, Fernandez-Twinn DS, Pantaleao LC, Carr SK, Ferland-Mccollough D, Yeo GS, Bushell M \& Ozanne SE 2016 Maternal obesity in pregnancy developmentally programs adipose tissue inflammation in young, lean male mice offspring. Endocrinology 157 4246-4256. (https://doi.org/10.1210/en.2016-1314)

Alonso-Magdalena P, Morimoto S, Ripoll C, Fuentes E \& Nadal A 2006 The estrogenic effect of bisphenol A disrupts pancreatic beta-cell function in vivo and induces insulin resistance. Environmental Health Perspectives 114 106-112. (https://doi.org/10.1289/ehp.8451)

Alonso-Magdalena P, Vieira E, Soriano S, Menes L, Burks D, Quesada I \& Nadal A 2010 Bisphenol A exposure during pregnancy disrupts glucose homeostasis in mothers and adult male offspring. Environmental Health Perspectives 118 1243-1250. (https://doi. org/10.1289/ehp.1001993)

Ando M, Saito H \& Wakisaka I 1985 Transfer of polychlorinated biphenyls (PCBs) to newborn infants through the placenta and mothers' milk. Archives of Environmental Contamination and Toxicology 14 51-57. (https://doi.org/10.1007/bf01055761)

Angle BM, Do RP, Ponzi D, Stahlhut RW, Drury BE, Nagel SC, Welshons WV, Besch-Williford CL, Palanza P, Parmigiani S, et al. 2013 Metabolic disruption in male mice due to fetal exposure to low but not high doses of bisphenol A (BPA): evidence for effects on body weight, food intake, adipocytes, leptin, adiponectin, insulin and glucose regulation. Reproductive Toxicology 42 256-268. (https://doi. org/10.1016/j.reprotox.2013.07.017)

Arnon L, Hazut N, Tabachnik T, Weller A \& Koren L 2016 Maternal testosterone and reproductive outcome in a rat model of obesity. Theriogenology 86 1042-1047. (https://doi.org/10.1016/j. theriogenology.2016.03.033)

Ashino NG, Saito KN, Souza FD, Nakutz FS, Roman EA, Velloso LA, Torsoni AS \& Torsoni MA 2012 Maternal high-fat feeding through pregnancy and lactation predisposes mouse offspring to molecular insulin resistance and fatty liver. Journal of Nutritional Biochemistry $\mathbf{2 3}$ 341-348. (https://doi.org/10.1016/j.jnutbio.2010.12.011)

Ayyavoo A, Derraik JG, Hofman PL, Biggs J, Bloomfield FH, Cormack BE, Stone P \& Cutfield WS 2013 Severe hyperemesis gravidarum is associated with reduced insulin sensitivity in the offspring in childhood. Journal of Clinical Endocrinology and Metabolism 98 3263-3268. (https://doi.org/10.1210/jc.2013-2043)

Bannister AJ \& Kouzarides T 2011 Regulation of chromatin by histone modifications. Cell Research 21 381-395. (https://doi.org/10.1038/ cr.2011.22)

Bansal A, Rashid C, Xin F, Li C, Polyak E, Duemler A, Van Der Meer T, Stefaniak M, Wajid S, Doliba N, et al. 2017 Sex- and dose-specific effects of maternal bisphenol A exposure on pancreatic islets of firstand second-generation adult mice offspring. Environmental Health Perspectives 125 097022. (https://doi.org/10.1289/EHP1674)

Bansal A, Henao-Mejia J \& Simmons RA 2018 Immune system: an emerging player in mediating effects of endocrine disruptors on metabolic health. Endocrinology 159 32-45. (https://doi.org/10.1210/ en.2017-00882)

Barker DJ 2004 The developmental origins of adult disease. Journal of the American College of Nutrition 23 (Supplement) 588S-595S. (https://doi. org/10.1080/07315724.2004.10719428)
Barker DJ 2005 The developmental origins of insulin resistance. Hormone Research 64 (Supplement 3) 2-7. (https://doi.org/10.1159/000089311)

Barker DJ 2007 The origins of the developmental origins theory. Journal of Internal Medicine 261 412-417. (https://doi.org/10.1111/j.13652796.2007.01809.x)

Barouki R, Gluckman PD, Grandjean P, Hanson M \& Heindel JJ 2012 Developmental origins of non-communicable disease: implications for research and public health. Environmental Health 11 42. (https:// doi.org/10.1186/1476-069X-11-42)

Barrett ES \& Swan SH 2015 Stress and androgen activity during fetal development. Endocrinology 156 3435-3441. (https://doi.org/10.1210/ en.2015-1335)

Bayol SA, Simbi BH \& Stickland NC 2005 A maternal cafeteria diet during gestation and lactation promotes adiposity and impairs skeletal muscle development and metabolism in rat offspring at weaning. Journal of Physiology 567 951-961. (https://doi.org/10.1113/ jphysiol.2005.088989)

Bellamy L, Casas JP, Hingorani AD \& Williams D 2009 Type 2 diabetes mellitus after gestational diabetes: a systematic review and metaanalysis. Lancet 373 1773-1779. (https://doi.org/10.1016/S01406736(09)60731-5)

Benatti RO, Melo AM, Borges FO, Ignacio-Souza LM, Simino LAP, Milanski M, Velloso LA, Torsoni MA \& Torsoni AS 2014 Maternal high-fat diet consumption modulates hepatic lipid metabolism and microRNA-122 (miR-122) and microRNA-370 (miR-370) expression in offspring. British Journal of Nutrition 111 2112-2122. (https://doi. org/10.1017/S0007114514000579)

Berenbaum SA 2002 Prenatal androgens and sexual differentiation of behavior. In Developmental Endocrinology: From Research to Clinical Practice. Eds EA Eugster \& OH Pescovitz. Totowa, NJ, USA: Humana Press. (https://doi.org/10.1111/j.1467-9280.1992.tb00028.x)

Berends LM, Fernandez-Twinn DS, Martin-Gronert MS, Cripps RL \& Ozanne SE 2013 Catch-up growth following intra-uterine growthrestriction programmes an insulin-resistant phenotype in adipose tissue. International Journal of Obesity 37 1051-1057. (https://doi. org/10.1038/ijo.2012.196)

Bianco ME \& Josefson JL 2019 Hyperglycemia during pregnancy and long-term offspring outcomes. Current Diabetes Reports 19143. (https://doi.org/10.1007/s11892-019-1267-6)

Boney CM, Verma A, Tucker R \& Vohr BR 2005 Metabolic syndrome in childhood: association with birth weight, maternal obesity, and gestational diabetes mellitus. Pediatrics 115 e290-e296. (https://doi. org/10.1542/peds.2004-1808)

Bowman JD \& Choudhury M 2016 Phthalates in neonatal health: friend or foe? Journal of Developmental Origins of Health and Disease 7 652-664. (https://doi.org/10.1017/S2040174416000349)

Breier BH, Vickers MH, Ikenasio BA, Chan KY \& Wong WP 2001 Fetal programming of appetite and obesity. Molecular and Cellular Endocrinology 185 73-79. (https://doi.org/10.1016/s03037207(01)00634-7)

Breton C 2013 The hypothalamus-adipose axis is a key target of developmental programming by maternal nutritional manipulation. Journal of Endocrinology 216 R19-R31. (https://doi.org/10.1530/JOE12-0157)

Bringhenti I, Schultz A, Rachid T, Bomfim MA, Mandarim-deLacerda CA \& Aguila MB 2011 An early fish oil-enriched diet reverses biochemical, liver and adipose tissue alterations in male offspring from maternal protein restriction in mice. Journal of Nutritional Biochemistry 22 1009-1014.

Bringhenti I, Ornellas F, Mandarim-De-Lacerda CA \& Aguila MB 2016 The insulin-signaling pathway of the pancreatic islet is impaired in adult mice offspring of mothers fed a high-fat diet. Nutrition 32 1138-1143. (https://doi.org/10.1016/j.nut.2016.03.001)

Buckley AJ, Keseru B, Briody J, Thompson M, Ozanne SE \& Thompson CH 2005 Altered body composition and metabolism in the male offspring of high fat-fed rats. Metabolism: Clinical 
and Experimental 54 500-507. (https://doi.org/10.1016/j. metabol.2004.11.003)

Burgos-Moron E, Abad-Jimenez Z, Maranon AM, Iannantuoni F, Escribano-Lopez I, Lopez-Domenech S, Salom C, Jover A, Mora V, Roldan I, et al. 2019 Relationship between oxidative stress, ER stress, and inflammation in type 2 diabetes: the battle continues. Journal of Clinical Medicine 8 E1385. (https://doi.org/10.3390/jcm8091385)

Burt BE, Hess BW, Nathanielsz PW \& Ford SP 2007 Flock differences in the impact of maternal dietary restriction on offspring growth and glucose tolerance in female offspring. Society of Reproduction and Fertility Supplement 64 411-424. (https://doi.org/10.5661/rdr-vi-411)

Caldwell AS, Middleton LJ, Jimenez M, Desai R, Mcmahon AC, Allan CM, Handelsman DJ \& Walters KA 2014 Characterization of reproductive, metabolic, and endocrine features of polycystic ovary syndrome in female hyperandrogenic mouse models. Endocrinology 155 3146-3159. (https://doi.org/10.1210/en.2014-1196)

Camacho LE, Chen X, Hay Jr WW \& Limesand SW 2017 Enhanced insulin secretion and insulin sensitivity in young lambs with placental insufficiency-induced intrauterine growth restriction. American Journal of Physiology: Regulatory, Integrative and Comparative Physiology 313 R101-R109. (https://doi.org/10.1152/ ajpregu.00068.2017)

Cao-Lei L, Laplante DP \& King S 2016 Prenatal maternal stress and epigenetics: review of the human research. Current Molecular Biology Reports 2 16-25. (https://doi.org/10.1007/s40610-016-0030-x)

Cardoso RC \& Padmanabhan V 2019 Prenatal steroids and metabolic dysfunction: lessons from sheep. Annual Review of Animal Biosciences 7 337-360. (https://doi.org/10.1146/annurevanimal-020518-115154)

Cardoso RC, Veiga-Lopez A, Moeller J, Beckett E, Pease A, Keller E, Madrigal V, Chazenbalk G, Dumesic D \& Padmanabhan V 2016 Developmental programming: impact of gestational steroid and metabolic milieus on adiposity and insulin sensitivity in prenatal testosterone-treated female sheep. Endocrinology 157 522-535. (https://doi.org/10.1210/en.2015-1565)

Cerf ME, Williams K, Nkomo XI, Muller CJ, Du Toit DF, Louw J \& WolfeCoote SA 2005 Islet cell response in the neonatal rat after exposure to a high-fat diet during pregnancy. American Journal of Physiology: Regulatory, Integrative and Comparative Physiology 288 R1122-R1128. (https://doi.org/10.1152/ajpregu.00335.2004)

Cernea M, Phillips R, Padmanabhan V, Coolen LM \& Lehman MN 2016 Prenatal testosterone exposure decreases colocalization of insulin receptors in kisspeptin/neurokinin B/dynorphin and agouti-related peptide neurons of the adult ewe. European Journal of Neuroscience $\mathbf{4 4}$ 2557-2568. (https://doi.org/10.1111/ejn.13373)

Chang W, Goodarzi MO, Williams H, Magoffin DA, Pall M \& Azziz R 2008 Adipocytes from women with polycystic ovary syndrome demonstrate altered phosphorylation and activity of glycogen synthase kinase 3. Fertility and Sterility 90 2291-2297. (https://doi. org/10.1016/j.fertnstert.2007.10.025)

Chang H, Wang D, Xia W, Pan X, Huo W, Xu S \& Li Y 2016 Epigenetic disruption and glucose homeostasis changes following low-dose maternal bisphenol A exposure. Toxicology Research 5 1400-1409. (https://doi.org/10.1039/c6tx00047a)

Chang E, Hafner H, Varghese M, Griffin C, Clemente J, Islam M, Carlson Z, Zhu A, Hak L, Abrishami S, et al. 2019 Programming effects of maternal and gestational obesity on offspring metabolism and metabolic inflammation. Scientific Reports 9 16027. (https://doi. org/10.1038/s41598-019-52583-x)

Chen SY, Hwang JS, Sung FC, Lin CY, Hsieh CJ, Chen PC \& Su TC 2017 Mono-2-ethylhexyl phthalate associated with insulin resistance and lower testosterone levels in a young population. Environmental Pollution 225 112-117. (https://doi.org/10.1016/j.envpol.2017.03.037)

Chu PW, Yang ZJ, Huang HH, Chang AA, Cheng YC, Wu GJ \& Lan HC 2018 Low-dose bisphenol A activates the ERK signaling pathway and attenuates steroidogenic gene expression in human placental cells.
Biology of Reproduction 98 250-258. (https://doi.org/10.1093/biolre/ iox162)

Ciaraldi TP, El-Roeiy A, Madar Z, Reichart D, Olefsky JM \& Yen SS 1992 Cellular mechanisms of insulin resistance in polycystic ovarian syndrome. Journal of Clinical Endocrinology and Metabolism $\mathbf{7 5}$ 577-583. (https://doi.org/10.1210/jcem.75.2.1322430)

Ciaraldi TP, Aroda V, Mudaliar S, Chang RJ \& Henry RR 2009 Polycystic ovary syndrome is associated with tissue-specific differences in insulin resistance. Journal of Clinical Endocrinology and Metabolism 94 157-163. (https://doi.org/10.1210/jc.2008-1492)

Ciccarone F, Tagliatesta S, Caiafa P \& Zampieri M 2018 DNA methylation dynamics in aging: how far are we from understanding the mechanisms? Mechanisms of Ageing and Development 174 3-17. (https://doi.org/10.1016/j.mad.2017.12.002)

Codagnone MG, Spichak S, O'Mahony SM, O'Leary OF, Clarke G, Stanton C, Dinan TG \& Cryan JF 2019 Programming bugs: microbiota and the developmental origins of brain health and disease. Biological Psychiatry 85 150-163. (https://doi.org/10.1016/j. biopsych.2018.06.014)

Collado MC, Isolauri E, Laitinen K \& Salminen S 2010 Effect of mother's weight on infant's microbiota acquisition, composition, and activity during early infancy: a prospective follow-up study initiated in early pregnancy. American Journal of Clinical Nutrition 92 1023-1030. (https://doi.org/10.3945/ajcn.2010.29877)

Constantinof A, Moisiadis VG \& Matthews SG 2016 Programming of stress pathways: a transgenerational perspective. Journal of Steroid Biochemistry and Molecular Biology 160 175-180. (https://doi. org/10.1016/j.jsbmb.2015.10.008)

Corbould A \& Dunaif A 2007 The adipose cell lineage is not intrinsically insulin resistant in polycystic ovary syndrome. Metabolism: Clinical and Experimental 56 716-722. (https://doi.org/10.1016/j. metabol.2006.12.021)

Cree-Green M, Newcomer BR, Coe G, Newnes L, Baumgartner A, Brown MS, Pyle L, Reusch JE \& Nadeau KJ 2015 Peripheral insulin resistance in obese girls with hyperandrogenism is related to oxidative phosphorylation and elevated serum free fatty acids. American Journal of Physiology: Endocrinology and Metabolism 308 E726-E733. (https:// doi.org/10.1152/ajpendo.00619.2014)

Cree-Green M, Rahat H, Newcomer BR, Bergman BC, Brown MS, Coe GV, Newnes L, Garcia-Reyes Y, Bacon S, Thurston JE, et al. 2017 Insulin resistance, hyperinsulinemia, and mitochondria dysfunction in nonobese girls with polycystic ovarian syndrome. Journal of the Endocrine Society 1 931-944. (https://doi.org/10.1210/js.2017-00192)

Dalziel SR, Walker NK, Parag V, Mantell C, Rea HH, Rodgers A \& Harding JE 2005 Cardiovascular risk factors after antenatal exposure to betamethasone: 30 -year follow-up of a randomised controlled trial. Lancet 365 1856-1862. (https://doi.org/10.1016/S01406736(05)66617-2)

Dancause KN, Veru F, Andersen RE, Laplante DP \& King S 2013 Prenatal stress due to a natural disaster predicts insulin secretion in adolescence. Early Human Development 89 773-776. (https://doi. org/10.1016/j.earlhumdev.2013.06.006)

Davegardh C, Garcia-Calzon S, Bacos K \& Ling C 2018 DNA methylation in the pathogenesis of type 2 diabetes in humans. Molecular Metabolism 14 12-25. (https://doi.org/10.1016/j.molmet.2018.01.022)

De Falco M, Forte M \& Laforgia V 2015 Estrogenic and anti-androgenic endocrine disrupting chemicals and their impact on the male reproductive system. Frontiers in Environmental Science 3 165. (https:// doi.org/10.3389/fenvs.2015.00003)

De Rosa S, Arcidiacono B, Chiefari E, Brunetti A, Indolfi C \& Foti DP 2018 Type 2 diabetes mellitus and cardiovascular disease: genetic and epigenetic links. Frontiers in Endocrinology 9 2. (https://doi. org/10.3389/fendo.2018.00002)

Dearden L, Bouret SG \& Ozanne SE 2018 Sex and gender differences in developmental programming of metabolism. Molecular Metabolism 15 8-19. (https://doi.org/10.1016/j.molmet.2018.04.007) https://joe.bioscientifica.com

https://doi.org/10.1530/JOE-20-0044 (c) 2020 Society for Endocrinology Published by Bioscientifica Ltd.
Printed in Great Britain 
Desai M, Jellyman JK \& Ross MG 2015 Epigenomics, gestational programming and risk of metabolic syndrome. International Journal of Obesity 39 633-641. (https://doi.org/10.1038/ijo.2015.13)

Desplats P, Gutierrez AM, Antonelli MC \& Frasch MG 2019 Microglial memory of early life stress and inflammation: susceptibility to neurodegeneration in adulthood. Neuroscience and Biobehavioral Reviews [epub]. (https://doi.org/10.1016/j.neubiorev.2019.10.013)

Dewi M, Carlson SE, Gustafson KM, Sullivan DK, Wick JA \& Hull HR 2017 Programming of infant neurodevelopment by maternal obesity: potential role of maternal inflammation and insulin resistance. Asia Pacific Journal of Clinical Nutrition 26 S36-S39. (https://doi. org/10.6133/apjcn.062017.s11)

Diamant YZ, Metzger BE, Freinkel N \& Shafrir E 1982 Placental lipid and glycogen content in human and experimental diabetes mellitus. American Journal of Obstetrics and Gynecology 144 5-11. (https://doi. org/10.1016/0002-9378(82)90385-4)

Diamanti-Kandarakis E, Bourguignon JP, Giudice LC, Hauser R, Prins GS, Soto AM, Zoeller RT \& Gore AC 2009 Endocrine-disrupting chemicals: an Endocrine Society scientific statement. Endocrine Reviews 30 293-342. (https://doi.org/10.1210/er.2009-0002)

Dimitriadis G, Mitrou P, Lambadiari V, Maratou E \& Raptis SA 2011 Insulin effects in muscle and adipose tissue. Diabetes Research and Clinical Practice 93 (Supplement 1) S52-S59. (https://doi.org/10.1016/ S0168-8227(11)70014-6)

Dirven BCJ, Homberg JR, Kozicz T \& Henckens MJAG 2017 Epigenetic programming of the neuroendocrine stress response by adult life stress. Journal of Molecular Endocrinology 59 R11-R31. (https://doi. org/10.1530/JME-17-0019)

Dong M, Zheng Q, Ford SP, Nathanielsz PW \& Ren J 2013 Maternal obesity, lipotoxicity and cardiovascular diseases in offspring. Journal of Molecular and Cellular Cardiology 55 111-116. (https://doi. org/10.1016/j.yjmcc.2012.08.023)

Drake AJ, Walker BR \& Seckl JR 2005 Intergenerational consequences of fetal programming by in utero exposure to glucocorticoids in rats. American Journal of Physiology: Regulatory, Integrative and Comparative Physiology 288 R34-R38. (https://doi.org/10.1152/ ajpregu.00106.2004)

Dudele A, Hougaard KS, Kjolby M, Hokland M, Winther G, Elfving B, Wegener G, Nielsen AL, Larsen A, Nohr MK, et al. 2017 Chronic maternal inflammation or high-fat-feeding programs offspring obesity in a sex-dependent manner. International Journal of Obesity $\mathbf{4 1}$ 1420-1426. (https://doi.org/10.1038/ijo.2017.136)

Dufty AM, Clobert J \& Møller AP 2002 Hormones, developmental plasticity and adaptation. Trends in Ecology and Evolution 17 190-196. (https://doi.org/10.1016/S0169-5347(02)02498-9)

Dumesic DA, Abbott DH \& Padmanabhan V 2007 Polycystic ovary syndrome and its developmental origins. Reviews in Endocrine and Metabolic Disorders 8 127-141. (https://doi.org/10.1007/s11154-0079046-0)

Dumesic DA, Phan JD, Leung KL, Grogan TR, Ding X, Li X, Hoyos LR, Abbott DH \& Chazenbalk GD 2019 Adipose insulin resistance in normal-weight women with polycystic ovary syndrome. Journal of Clinical Endocrinology and Metabolism 104 2171-2183. (https://doi. org/10.1210/jc.2018-02086)

Dunkel Schetter C 2011 Psychological science on pregnancy: stress processes, biopsychosocial models, and emerging research issues. Annual Review of Psychology 62 531-558. (https://doi.org/10.1146/ annurev.psych.031809.130727)

Duque-Guimaraes DE \& Ozanne SE 2013 Nutritional programming of insulin resistance: causes and consequences. Trends in Endocrinology and Metabolism 24 525-535. (https://doi.org/10.1016/j. tem.2013.05.006)

Ebrahimi R, Bahiraee A, Niazpour F, Emamgholipour S \& Meshkani R 2019 The role of microRNAs in the regulation of insulin signaling pathway with respect to metabolic and mitogenic cascades: a review.
Journal of Cellular Biochemistry 120 19290-19309. (https://doi. org/10.1002/jcb.29299)

Eisner JR, Dumesic DA, Kemnitz JW \& Abbott DH 2000 Timing of prenatal androgen excess determines differential impairment in insulin secretion and action in adult female rhesus monkeys. Journal of Clinical Endocrinology and Metabolism 85 1206-1210. (https://doi. org/10.1210/jcem.85.3.6453)

Eisner JR, Dumesic DA, Kemnitz JW, Colman RJ \& Abbott DH 2003 Increased adiposity in female rhesus monkeys exposed to androgen excess during early gestation. Obesity Research 11 279-286. (https:// doi.org/10.1038/oby.2003.42)

El-Hefnawy T, Hernandez C \& Stabile LP 2017 The endocrine disrupting alkylphenols and 4,4'-DDT interfere with estrogen conversion and clearance by mouse liver cytosol. Reproductive Biology 17 185-192. (https://doi.org/10.1016/j.repbio.2017.04.003)

Elliott HR, Sharp GC, Relton CL \& Lawlor DA 2019 Epigenetics and gestational diabetes: a review of epigenetic epidemiology studies and their use to explore epigenetic mediation and improve prediction. Diabetologia 62 2171-2178. (https://doi.org/10.1007/s00125-01905011-8)

Erion KA \& Corkey BE 2017 Hyperinsulinemia: a cause of obesity? Current Obesity Reports 6 178-186. (https://doi.org/10.1007/s13679-0170261-z)

Esser N, Legrand-Poels S, Piette J, Scheen AJ \& Paquot N 2014 Inflammation as a link between obesity, metabolic syndrome and type 2 diabetes. Diabetes Research and Clinical Practice 105 141-150.

Facchi JC, De Lima TAL, De Oliveira LR, De Oliveira Costermani H, De Souza Miranda GD \& De Oliveira JC 2019 Perinatal programming of metabolic diseases: the role of glucocorticoids. Metabolism $\mathbf{1 0 4}$ 154047. (https://doi.org/10.1016/j.metabol.2019.154047)

Faulds MH, Zhao C, Dahlman-Wright K \& Gustafsson JÅ 2012 The diversity of sex steroid action: regulation of metabolism by estrogen signaling. Journal of Endocrinology 212 3-12. (https://doi.org/10.1530/ JOE-11-0044)

Faulk C, Kim JH, Jones TR, Mceachin RC, Nahar MS, Dolinoy DC \& Sartor MA 2015 Bisphenol A-associated alterations in genome-wide DNA methylation and gene expression patterns reveal sequencedependent and non-monotonic effects in human fetal liver. Environmental Epigenetics 1 dvv006. (https://doi.org/10.1093/eep/ dvv006)

Ferguson KK, Cantonwine DE, Rivera-Gonzalez LO, Loch-Caruso R, Mukherjee B, Anzalota Del Toro LV, Jimenez-Velez B, Calafat AM, Ye X, Alshawabkeh AN, et al. 2014 Urinary phthalate metabolite associations with biomarkers of inflammation and oxidative stress across pregnancy in Puerto Rico. Environmental Science and Technology 48 7018-7025. (https://doi.org/10.1021/es502076j)

Fernandez-Twinn DS, Wayman A, Ekizoglou S, Martin MS, Hales CN \& Ozanne SE 2005 Maternal protein restriction leads to hyperinsulinemia and reduced insulin-signaling protein expression in 21-mo-old female rat offspring. American Journal of Physiology: Regulatory, Integrative and Comparative Physiology 288 R368-R373. (https://doi.org/10.1152/ajpregu.00206.2004)

Fernandez-Twinn DS, Alfaradhi MZ, Martin-Gronert MS, DuqueGuimaraes DE, Piekarz A, Ferland-Mccollough D, Bushell M \& Ozanne SE 2014 Downregulation of IRS-1 in adipose tissue of offspring of obese mice is programmed cell-autonomously through post-transcriptional mechanisms. Molecular Metabolism 3 325-333. (https://doi.org/10.1016/j.molmet.2014.01.007)

Fernandez-Twinn DS, Blackmore HL, Siggens L, Giussani DA, Cross CM, Foo R \& Ozanne SE 2012 The programming of cardiac hypertrophy in the offspring by maternal obesity is associated with hyperinsulinemia, AKT, ERK, and mTOR activation. Endocrinology 153 5961-5971. (https://doi.org/10.1210/en.2012-1508)

Fernandez-Twinn DS, Hjort L, Novakovic B, Ozanne SE \& Saffery R 2019 Intrauterine programming of obesity and type 2 diabetes. https://joe.bioscientifica.com

https://doi.org/10.1530/JOE-20-0044 (c) 2020 Society for Endocrinology Published by Bioscientifica Ltd. Printed in Great Britain 
Diabetologia 62 1789-1801. (https://doi.org/10.1007/s00125-0194951-9)

Flamment M, Hajduch E, Ferre P \& Foufelle F 2012 New insights into ER stress-induced insulin resistance. Trends in Endocrinology and Metabolism 23 381-390. (https://doi.org/10.1016/j.tem.2012.06.003)

Ford SP, Hess BW, Schwope MM, Nijland MJ, Gilbert JS, Vonnahme KA, Means WJ, Han H \& Nathanielsz PW 2007 Maternal undernutrition during early to mid-gestation in the ewe results in altered growth, adiposity, and glucose tolerance in male offspring. Journal of Animal Science 85 1285-1294. (https://doi.org/10.2527/jas.2005-624)

Forger NG 2018 Past, present and future of epigenetics in brain sexual differentiation. Journal of Neuroendocrinology 30 e12492. (https://doi. org/10.1111/jne.12492)

Fowden AL \& Forhead AJ 2004 Endocrine mechanisms of intrauterine programming. Reproduction 127 515-526. (https://doi.org/10.1530/ rep.1.00033)

Franks PW, Pearson E \& Florez JC 2013 Gene-environment and genetreatment interactions in type 2 diabetes: progress, pitfalls, and prospects. Diabetes Care 36 1413-1421. (https://doi.org/10.2337/ dc12-2211)

Friedman JE 2015 Obesity and gestational diabetes mellitus pathways for programming in mouse, monkey, and man-where do we go next? The 2014 Norbert Freinkel award lecture. Diabetes Care 38 1402-1411. (https://doi.org/10.2337/dc15-0628)

Gaillard R 2015 Maternal obesity during pregnancy and cardiovascular development and disease in the offspring. European Journal of Epidemiology 30 1141-1152. (https://doi.org/10.1007/s10654-0150085-7)

Gardner DS, Tingey K, Van Bon BW, Ozanne SE, Wilson V, Dandrea J, Keisler DH, Stephenson T \& Symonds ME 2005 Programming of glucose-insulin metabolism in adult sheep after maternal undernutrition. American Journal of Physiology: Regulatory, Integrative and Comparative Physiology 289 R947-R954. (https://doi.org/10.1152/ ajpregu.00120.2005)

Gatford KL, Wintour EM, De Blasio MJ, Owens JA \& Dodic M 2000 Differential timing for programming of glucose homoeostasis, sensitivity to insulin and blood pressure by in utero exposure to dexamethasone in sheep. Clinical Science 98 553-560. (https://doi. org/10.1042/cs0980553)

Gauguier D, Bihoreau MT, Ktorza A, Berthault MF \& Picon L 1990 Inheritance of diabetes mellitus as consequence of gestational hyperglycemia in rats. Diabetes 39 734-739. (https://doi.org/10.2337/ diab.39.6.734)

Gavin JR, Roth J, Neville DM, De Meyts P \& Buell DN 1974 Insulindependent regulation of insulin receptor concentrations: a direct demonstration in cell culture. PNAS 71 84-88. (https://doi. org/10.1073/pnas.71.1.84)

George LA, Zhang L, Tuersunjiang N, Ma Y, Long NM, Uthlaut AB, Smith DT, Nathanielsz PW \& Ford SP 2012 Early maternal undernutrition programs increased feed intake, altered glucose metabolism and insulin secretion, and liver function in aged female offspring. American Journal of Physiology: Regulatory, Integrative and Comparative Physiology $\mathbf{3 0 2}$ R795-R804. (https://doi.org/10.1152/ajpregu.00241.2011)

Gluckman PD \& Hanson MA 2004 The developmental origins of the metabolic syndrome. Trends in Endocrinology and Metabolism 15 183-187. (https://doi.org/10.1016/j.tem.2004.03.002)

Godfrey KM, Reynolds RM, Prescott SL, Nyirenda M, Jaddoe VW, Eriksson JG \& Broekman BF 2017 Influence of maternal obesity on the long-term health of offspring. Lancet: Diabetes and Endocrinology 5 53-64. (https://doi.org/10.1016/S2213-8587(16)30107-3)

Gomes RM, Bueno FG, Schamber CR, De Mello JCP, De Oliveira JC, Francisco FA, Moreira VM, Junior MDF, Pedrino GR, De Freitas Mathias PC, et al. 2018 Maternal diet-induced obesity during suckling period programs offspring obese phenotype and hypothalamic leptin/insulin resistance. Journal of Nutritional Biochemistry 61 24-32. (https://doi.org/10.1016/i.jnutbio.2018.07.006)
Gomez-Lopez N, Motomura K, Miller D, Garcia-Flores V, Galaz J \& Romero R 2019 Inflammasomes: their role in normal and complicated pregnancies. Journal of Immunology 203 2757-2769. (https://doi. org/10.4049/jimmunol.1900901)

Gonzalez-Franquesa A \& Patti ME 2017 Insulin resistance and mitochondrial dysfunction. Advances in Experimental Medicine and Biology 982 465-520. (https://doi.org/10.1007/978-3-319-55330-6_25)

Goodrich JM, Ingle ME, Domino SE, Treadwell MC, Dolinoy DC, Burant C, Meeker JD \& Padmanabhan V 2019 First trimester maternal exposures to endocrine disrupting chemicals and metals and fetal size in the Michigan mother-infant pairs study. Journal of Developmental Origins of Health and Disease 10 447-458. (https://doi.org/10.1017/ S204017441800106X)

Gore AC, Chappell VA, Fenton SE, Flaws JA, Nadal A, Prins GS, Toppari J \& Zoeller RT 2015 EDC-2: the Endocrine Society's second scientific statement on endocrine-disrupting chemicals. Endocrine Reviews $\mathbf{3 6}$ E1-E150. (https://doi.org/10.1210/er.2015-1010)

Gozukara YM, Aytan H, Ertunc D, Tok EC, Demirturk F, Sahin S \& Aytan P 2015 Role of first trimester total testosterone in prediction of subsequent gestational diabetes mellitus. Journal of Obstetrics and Gynaecology Research 41 193-198. (https://doi.org/10.1111/ jog.12525)

Gu W, Wang Y, Qiu Z, Dong J, Wang Y \& Chen J 2018 Maternal exposure to nonylphenol during pregnancy and lactation induces microglial cell activation and pro-inflammatory cytokine production in offspring hippocampus. Science of the Total Environment 634 525-533. (https://doi.org/10.1016/j.scitotenv.2018.03.329)

Guo S 2014 Insulin signaling, resistance, and the metabolic syndrome: insights from mouse models into disease mechanisms. Journal of Endocrinology 220 T1-T23. (https://doi.org/10.1530/JOE-13-0327)

Gur TL, Shay L, Palkar AV, Fisher S, Varaljay VA, Dowd S \& Bailey MT 2017 Prenatal stress affects placental cytokines and neurotrophins, commensal microbes, and anxiety-like behavior in adult female offspring. Brain, Behavior, and Immunity 64 50-58. (https://doi. org/10.1016/j.bbi.2016.12.021)

Hales CN \& Barker DJ 1992 Type 2 (non-insulin-dependent) diabetes mellitus: the thrifty phenotype hypothesis. Diabetologia 35 595-601. (https://doi.org/10.1007/bf00400248)

Han H, Lee HA, Park B, Park B, Hong YS, Ha EH \& Park H 2019 Associations of phthalate exposure with lipid levels and insulin sensitivity index in children: a prospective cohort study. Science of the Total Environment 662 714-721. (https://doi.org/10.1016/j. scitotenv.2019.01.151)

Hansen SL, Svendsen PF, Jeppesen JF, Hoeg LD, Andersen NR, Kristensen JM, Nilas L, Lundsgaard AM, Wojtaszewski JFP, Madsbad S, et al. 2019 Molecular mechanisms in skeletal muscle underlying insulin resistance in women who are lean with polycystic ovary syndrome. Journal of Clinical Endocrinology and Metabolism 104 1841-1854. (https://doi.org/10.1210/jc.2018-01771)

Hariri N \& Thibault L 2010 High-fat diet-induced obesity in animal models. Nutrition Research Reviews 23 270-299. (https://doi. org/10.1017/S0954422410000168)

Hemmatzadeh M, Shomali N, Yousefzadeh Y, Mohammadi H, Ghasemzadeh A \& Yousefi M 2020 MicroRNAs: small molecules with a large impact on pre-eclampsia. Journal of Cellular Physiology $\mathbf{2 3 5}$ 3235-3248. (https://doi.org/10.1002/jcp.29286)

Hocking S, Samocha-Bonet D, Milner KL, Greenfield JR \& Chisholm DJ 2013 Adiposity and insulin resistance in humans: the role of the different tissue and cellular lipid depots. Endocrine Reviews $\mathbf{3 4}$ 463-500. (https://doi.org/10.1210/er.2012-1041)

Hogg K, Wood C, Mcneilly AS \& Duncan WC 2011 The in utero programming effect of increased maternal androgens and a direct fetal intervention on liver and metabolic function in adult sheep. PLOS ONE 6 e24877. (https://doi.org/10.1371/journal.pone.0024877)

Holmäng A, Svedberg J, Jennische E \& Bjorntorp P 1990 Effects of testosterone on muscle insulin sensitivity and morphology in female https://joe.bioscientifica.com

https://doi.org/10.1530/JOE-20-0044
(C) 2020 Society for Endocrinology Published by Bioscientifica Ltd. Printed in Great Britain 
rats. American Journal of Physiology 259 E555-E560. (https://doi. org/10.1152/ajpendo.1990.259.4.E555)

Hromadnikova I, Dvorakova L, Kotlabova K \& Krofta L 2019 The prediction of gestational hypertension, preeclampsia and fetal growth restriction via the first trimester screening of plasma exosomal C19MC microRNAs. International Journal of Molecular Sciences 20 E2972. (https://doi.org/10.3390/ijms20122972)

$\mathrm{Hu}$ M, Richard JE, Maliqueo M, Kokosar M, Fornes R, Benrick A, Jansson T, Ohlsson C, Wu X, Skibicka KP, et al. 2015 Maternal testosterone exposure increases anxiety-like behavior and impacts the limbic system in the offspring. PNAS 112 14348-14353. (https://doi. org/10.1073/pnas.1507514112)

Huang EY, Inoue T, Leone VA, Dalal S, Touw K, Wang Y, Musch MW, Theriault B, Higuchi K, Donovan S, et al. 2015 Using corticosteroids to reshape the gut microbiome: implications for inflammatory bowel diseases. Inflammatory Bowel Diseases 21 963-972. (https://doi. org/10.1097/MIB.0000000000000332)

Hunt BG, Wang YL, Chen MS, Wang SC \& Waltz SE 2017 Maternal diethylhexyl phthalate exposure affects adiposity and insulin tolerance in offspring in a PCNA-dependent manner. Environmental Research 159 588-594. (https://doi.org/10.1016/j.envres.2017.09.004)

Hyun K, Jeon J, Park K \& Kim J 2017 Writing, erasing and reading histone lysine methylations. Experimental and Molecular Medicine 49 e324. (https://doi.org/10.1038/emm.2017.11)

Ibanez CA, Vazquez-Martinez M, Leon-Contreras JC, Reyes-Castro LA, Rodriguez-Gonzalez GL, Bautista CJ, Nathanielsz PW \& Zambrano E 2018 Different statistical approaches to characterization of adipocyte size in offspring of obese rats: effects of maternal or offspring exercise intervention. Frontiers in Physiology 9 1571. (https://doi.org/10.3389/ fphys.2018.01571)

Ingvorsen C, Brix S, Ozanne SE \& Hellgren LI 2015 The effect of maternal Inflammation on foetal programming of metabolic disease. Acta Physiologica 214 440-449. (https://doi.org/10.1111/apha.12533)

Inoki K, Li Y, Zhu T, Wu J \& Guan KL 2002 TSC2 is phosphorylated and inhibited by Akt and suppresses mTOR signalling. Nature Cell Biology 4 648-657. (https://doi.org/10.1038/ncb839)

Iwabu M, Okada-Iwabu M, Yamauchi T \& Kadowaki T 2019 Adiponectin/ AdipoR research and its implications for lifestyle-related diseases. Frontiers in Cardiovascular Medicine 6 116. (https://doi.org/10.3389/ fcvm.2019.00116)

James-Todd T, Stahlhut R, Meeker JD, Powell SG, Hauser R, Huang T \& Rich-Edwards J 2012 Urinary phthalate metabolite concentrations and diabetes among women in the National Health and Nutrition Examination Survey (NHANES) 2001-2008. Environmental Health Perspectives 120 1307-1313. (https://doi.org/10.1289/ehp.1104717)

Javurek AB, Spollen WG, Johnson SA, Bivens NJ, Bromert KH, Givan SA \& Rosenfeld CS 2016 Effects of exposure to bisphenol A and ethinyl estradiol on the gut microbiota of parents and their offspring in a rodent model. Gut Microbes 7 471-485. (https://doi.org/10.1080/1949 0976.2016.1234657)

Jeve YB, Konje JC \& Doshani A 2015 Placental dysfunction in obese women and antenatal surveillance strategies. Best Practice and Research: Clinical Obstetrics and Gynaecology 29 350-364. (https://doi. org/10.1016/j.bpobgyn.2014.09.007)

Jost A 1983 Genetic and hormonal factors in sex differentiation of the brain. Psychoneuroendocrinology 8 183-193. (https://doi. org/10.1016/0306-4530(83)90055-0)

Jost A, Vigier B, Prepin J \& Perchellet JP 1973 Studies on sex differentiation in mammals. Recent Progress in Hormone Research 29 1-41. (https://doi.org/10.1016/b978-0-12-571129-6.50004-x)

Jou MY, Philipps AF \& Lonnerdal B 2010 Maternal zinc deficiency in rats affects growth and glucose metabolism in the offspring by inducing insulin resistance postnatally. Journal of Nutrition 140 1621-1627. (https://doi.org/10.3945/jn.109.119677)

Kabir ER, Rahman MS \& Rahman I 2015 A review on endocrine disruptors and their possible impacts on human health. Environmental
Toxicology and Pharmacology 40 241-258. (https://doi.org/10.1016/j. etap.2015.06.009)

Kahn BB \& Flier JS 2000 Obesity and insulin resistance. Journal of Clinical Investigation 106 473-481. (https://doi.org/10.1172/JCI10842)

Kalisch-Smith JI, Simmons DG, Dickinson H \& Moritz KM 2017 Review: Sexual dimorphism in the formation, function and adaptation of the placenta. Placenta 54 10-16. (https://doi.org/10.1016/j. placenta.2016.12.008)

Kamrani A, Alipourfard I, Ahmadi-Khiavi H, Yousefi M, Rostamzadeh D, Izadi M \& Ahmadi M 2019 The role of epigenetic changes in preeclampsia. BioFactors 45 712-724. (https://doi.org/10.1002/ biof.1542)

Kauffman AS, Thackray VG, Ryan GE, Tolson KP, Glidewell-Kenney CA, Semaan SJ, Poling MC, Iwata N, Breen KM, Duleba AJ, et al. 2015 A novel letrozole model recapitulates both the reproductive and metabolic phenotypes of polycystic ovary syndrome in female mice. Biology of Reproduction 93 69. (https://doi.org/10.1095/ biolreprod.115.131631)

Keelan JA 2018 Intrauterine inflammatory activation, functional progesterone withdrawal, and the timing of term and preterm birth. Journal of Reproductive Immunology 125 89-99. (https://doi. org/10.1016/j.jri.2017.12.004)

Kelley AS, Banker M, Goodrich JM, Dolinoy DC, Burant C, Domino SE, Smith YR, Song PXK \& Padmanabhan V 2019a Early pregnancy exposure to endocrine disrupting chemical mixtures are associated with inflammatory changes in maternal and neonatal circulation. Scientific Reports 9 5422. (https://doi.org/10.1038/s41598-01941134-z)

Kelley AS, Puttabyatappa M, Ciarelli JN, Zeng L, Smith YR, Lieberman R, Pennathur S \& Padmanabhan V $2019 b$ Prenatal testosterone excess disrupts placental function in a sheep model of polycystic ovary syndrome. Endocrinology 160 2663-2672. (https://doi.org/10.1210/ en.2019-00386)

Kelstrup L, Damm P, Mathiesen ER, Hansen T, Vaag AA, Pedersen O \& Clausen TD 2013 Insulin resistance and impaired pancreatic beta-cell function in adult offspring of women with diabetes in pregnancy. Journal of Clinical Endocrinology and Metabolism 98 3793-3801. (https://doi.org/10.1210/jc.2013-1536)

Kerr AG, Sinha I, Dadvar S, Arner P \& Dahlman I 2019 Epigenetic regulation of diabetogenic adipose morphology. Molecular Metabolism 25 159-167. (https://doi.org/10.1016/j.molmet.2019.04.009)

Kleinridders A, Ferris HA, Cai W \& Kahn CR 2014 Insulin action in brain regulates systemic metabolism and brain function. Diabetes $\mathbf{6 3}$ 2232-2243. (https://doi.org/10.2337/db14-0568)

Kohn MC, Lucier GW, Clark GC, Sewall C, Tritscher AM \& Portier CJ 1993 A mechanistic model of effects of dioxin on gene expression in the rat liver. Toxicology and Applied Pharmacology 120 138-154. (https://doi.org/10.1006/taap.1993.1096)

Kubo A, Ferrara A, Windham GC, Greenspan LC, Deardorff J, Hiatt RA, Quesenberry CP, Laurent C, Mirabedi AS \& Kushi LH 2014 Maternal hyperglycemia during pregnancy predicts adiposity of the offspring. Diabetes Care 37 2996-3002. (https://doi.org/10.2337/ dc14-1438)

Lang IA, Galloway TS, Scarlett A, Henley WE, Depledge M, Wallace RB \& Melzer D 2008 Association of urinary bisphenol A concentration with medical disorders and laboratory abnormalities in adults. JAMA $\mathbf{3 0 0}$ 1303-1310. (https://doi.org/10.1001/jama.300.11.1303)

Laubach ZM, Perng W, Dolinoy DC, Faulk CD, Holekamp KE \& Getty T 2018 Epigenetics and the maintenance of developmental plasticity: extending the signalling theory framework. Biological Reviews of the Cambridge Philosophical Society 93 1323-1338. (https://doi. org/10.1111/brv.12396)

Laugerette F, Vors C, Peretti N \& Michalski MC 2011 Complex links between dietary lipids, endogenous endotoxins and metabolic inflammation. Biochimie 93 39-45. (https://doi.org/10.1016/j. biochi.2010.04.016) https://joe.bioscientifica.com

https://doi.org/10.1530/JOE-20-0044 (c) 2020 Society for Endocrinology Published by Bioscientifica Ltd. Printed in Great Britain 
Lee WC, Fisher M, Davis K, Arbuckle TE \& Sinha SK 2017 Identification of chemical mixtures to which Canadian pregnant women are exposed: the MIREC study. Environment International 99 321-330. (https://doi. org/10.1016/j.envint.2016.12.015)

Lema SC 2020 Hormones, developmental plasticity, and adaptive evolution: endocrine flexibility as a catalyst for 'plasticity-first' phenotypic divergence. Molecular and Cellular Endocrinology 502 110678. (https://doi.org/10.1016/j.mce.2019.110678)

Lewis DS, Bertrand HA, McMahan CA, McGill HC, Carey KD \& Masoro EJ 1986 Preweaning food intake influences the adiposity of young adult baboons. Journal of Clinical Investigation 78 899-905. (https://doi org/10.1172/JCI112678)

Li Y, He Y, Qi L, Jaddoe VW, Feskens EJ, Yang X, Ma G \& Hu FB 2010 Exposure to the Chinese famine in early life and the risk of hyperglycemia and type 2 diabetes in adulthood. Diabetes $\mathbf{5 9}$ 2400-2406. (https://doi.org/10.2337/db10-0385)

Li M, Sloboda DM \& Vickers MH 2011 Maternal obesity and developmental programming of metabolic disorders in offspring: evidence from animal models. Experimental Diabetes Research 2011 592408. (https://doi.org/10.1155/2011/592408)

Li M, Wang M \& Donovan SM 2014a Early development of the gut microbiome and immune-mediated childhood disorders. Seminars in Reproductive Medicine 32 74-86. (https://doi. org/10.1055/s-0033-1361825)

Li G, Chang H, Xia W, Mao Z, Li Y \& Xu S 2014b F0 maternal BPA exposure induced glucose intolerance of $\mathrm{F} 2$ generation through DNA methylation change in Gck. Toxicology Letters 228 192-199. (https:// doi.org/10.1016/j.toxlet.2014.04.012)

Lin Y, Wei J, Li Y, Chen J, Zhou Z, Song L, Wei Z, Lv Z, Chen X, Xia W, et al. 2011 a Developmental exposure to di(2-ethylhexyl) phthalate impairs endocrine pancreas and leads to long-term adverse effects on glucose homeostasis in the rat. American Journal of Physiology: Endocrinology and Metabolism 301 E527-E538. (https://doi. org/10.1152/ajpendo.00233.2011)

Lin Y, Han XF, Fang ZF, Che LQ, Nelson J, Yan TH \& Wu D $2011 b$ Beneficial effects of dietary fibre supplementation of a high-fat diet on fetal development in rats. British Journal of Nutrition 106 510-518. (https://doi.org/10.1017/S0007114511000614)

Lin Y, Ding D, Huang Q, Liu Q, Lu H, Lu Y, Chi Y, Sun X, Ye G, Zhu H, et al. 2017 Downregulation of miR-192 causes hepatic steatosis and lipid accumulation by inducing SREBF1: novel mechanism for bisphenol A-triggered non-alcoholic fatty liver disease. Biochimica et Biophysica Acta: Molecular and Cell Biology of Lipids 1862 869-882. (https://doi.org/10.1016/j.bbalip.2017.05.001)

Long NM, George LA, Uthlaut AB, Smith DT, Nijland MJ, Nathanielsz PW \& Ford SP 2010 Maternal obesity and increased nutrient intake before and during gestation in the ewe results in altered growth, adiposity, and glucose tolerance in adult offspring. Journal of Animal Science $\mathbf{8 8}$ 3546-3553. (https://doi.org/10.2527/jas.2010-3083)

Long NM, Shasa DR, Ford SP \& Nathanielsz PW 2012 Growth and insulin dynamics in two generations of female offspring of mothers receiving a single course of synthetic glucocorticoids. American Journal of Obstetrics and Gynecology 207 203.e1-203.e8. (https://doi. org/10.1016/j.ajog.2012.06.024)

Long NM, Smith DT, Ford SP \& Nathanielsz PW 2013 Elevated glucocorticoids during ovine pregnancy increase appetite and produce glucose dysregulation and adiposity in their granddaughters in response to ad libitum feeding at 1 year of age. American Journal of Obstetrics and Gynecology 209 353.e1-353.e9. (https://doi. org/10.1016/j.ajog.2013.05.051)

Lorigooini Z, Sadeghi Dehsahraei K, Bijad E, Habibian Dehkordi S \& Amini-Khoei H 2019 Trigonelline through the attenuation of oxidative stress exerts antidepressant- and anxiolytic-like effects in a mouse model of maternal separation stress. Pharmacology [epub]. (https://doi.org/10.1159/000503728)
Lu C, Cardoso RC, Puttabyatappa M \& Padmanabhan V 2016 Developmental programming: prenatal testosterone excess and insulin signaling disruptions in female sheep. Biology of Reproduction 94 113. (https://doi.org/10.1095/biolreprod.115.136283)

Luense LJ, Veiga-Lopez A, Padmanabhan V \& Christenson LK 2011 Developmental programming: gestational testosterone treatment alters fetal ovarian gene expression. Endocrinology 152 4974-4983. (https://doi.org/10.1210/en.2011-1182)

Luo ZC, Fraser WD, Julien P, Deal CL, Audibert F, Smith GN, Xiong X \& Walker M 2006 Tracing the origins of 'fetal origins' of adult diseases: programming by oxidative stress? Medical Hypotheses 66 38-44. (https://doi.org/10.1016/j.mehy.2005.08.020)

Lushchak VI 2014 Free radicals, reactive oxygen species, oxidative stress and its classification. Chemico-Biological Interactions 224 164-175. (https://doi.org/10.1016/j.cbi.2014.10.016)

Ly A, Ishiguro L, Kim D, Im D, Kim SE, Sohn KJ, Croxford R \& Kim YI 2016 Maternal folic acid supplementation modulates DNA methylation and gene expression in the rat offspring in a gestation period-dependent and organ-specific manner. Journal of Nutritional Biochemistry 33 103-110. (https://doi.org/10.1016/j. jnutbio.2016.03.018)

Lynch C, Chan CS \& Drake AJ 2017 Early life programming and the risk of non-alcoholic fatty liver disease. Journal of Developmental Origins of Health and Disease 8 263-272. (https://doi.org/10.1017/ S2040174416000805)

Ma D, Shield JP, Dean W, Leclerc I, Knauf C, burcelin r Ré, Rutter GA \& Kelsey G 2004 Impaired glucose homeostasis in transgenic mice expressing the human transient neonatal diabetes mellitus locus, TNDM. Journal of Clinical Investigation 114 339-348. (https://doi. org/10.1172/JCI19876)

Ma Y, Xia W, Wang DQ, Wan YJ, Xu B, Chen X, Li YY \& Xu SQ 2013 Hepatic DNA methylation modifications in early development of rats resulting from perinatal BPA exposure contribute to insulin resistance in adulthood. Diabetologia 56 2059-2067. (https://doi.org/10.1007/ s00125-013-2944-7)

Maliqueo M, Lara HE, Sanchez F, Echiburu B, Crisosto N \& Sir-Petermann T 2013 Placental steroidogenesis in pregnant women with polycystic ovary syndrome. European Journal of Obstetrics, Gynecology, and Reproductive Biology 166 151-155. (https://doi.org/10.1016/j.ejogrb.2012.10.015)

Maliqueo M, Cruz G, Espina C, Contreras I, Garcia M, Echiburu B \& Crisosto N 2017 Obesity during pregnancy affects sex steroid concentrations depending on fetal gender. International Journal of Obesity 41 1636-1645. (https://doi.org/10.1038/ijo.2017.159)

Mannerås L, Cajander S, Holmang A, Seleskovic Z, Lystig T, Lonn M \& Stener-Victorin E 2007 A new rat model exhibiting both ovarian and metabolic characteristics of polycystic ovary syndrome. Endocrinology 148 3781-3791. (https://doi.org/10.1210/en.2007-0168)

Manneras-Holm L, Leonhardt H, Kullberg J, Jennische E, Oden A, Holm G, Hellstrom M, Lonn L, Olivecrona G, Stener-Victorin E, et al. 2011 Adipose tissue has aberrant morphology and function in PCOS: enlarged adipocytes and low serum adiponectin, but not circulating sex steroids, are strongly associated with insulin resistance. Journal of Clinical Endocrinology and Metabolism 96 E304-E311. (https://doi. org/10.1210/jc.2010-1290)

Martinez-Ibarra A, Martinez-Razo LD, Vazquez-Martinez ER, MartinezCruz N, Flores-Ramirez R, Garcia-Gomez E, Lopez-Lopez M, OrtegaGonzalez C, Camacho-Arroyo I \& Cerbon M 2019 Unhealthy levels of phthalates and bisphenol A in Mexican pregnant women with gestational diabetes and its Association to Altered Expression of miRNAs involved with metabolic disease. International Journal of Molecular Sciences 20 E3343. (https://doi.org/10.3390/ijms20133343)

Martin-Gronert MS, Fernandez-Twinn DS, Poston L \& Ozanne SE 2010 Altered hepatic insulin signalling in male offspring of obese mice. Journal of Developmental Origins of Health and Disease 1 184-191. (https://doi.org/10.1017/S2040174410000231) https://joe.bioscientifica.com https://doi.org/10.1530/JOE-20-0044 (c) 2020 Society for Endocrinology Published by Bioscientifica Ltd. Printed in Great Britain 
Masuda Y, Kagawa R, Kuroki H, Kuratsune M, Yoshimura T, Taki I, Kusuda M, Yamashita F \& Hayashi M 1978 Transfer of polychlorinated biphenyls from mothers to foetuses and infants. Food and Cosmetics Toxicology 16 543-546. (https://doi.org/10.1016/s00156264(78)80221-1)

Matsuzawa-Nagata N, Takamura T, Ando H, Nakamura S, Kurita S, Misu H, Ota T, Yokoyama M, Honda M, Miyamoto K, et al. 2008 Increased oxidative stress precedes the onset of high-fat diet-induced insulin resistance and obesity. Metabolism: Clinical and Experimental 57 1071-1077. (https://doi.org/10.1016/j.metabol.2008.03.010)

Mauvais-Jarvis F 2015 Sex differences in metabolic homeostasis, diabetes, and obesity. Biology of Sex Differences 6 14. (https://doi.org/10.1186/ s13293-015-0033-y)

McCarthy MM, Nugent BM \& Lenz KM 2017 Neuroimmunology and neuroepigenetics in the establishment of sex differences in the brain. Nature Reviews: Neuroscience 18 471-484. (https://doi.org/10.1038/ nrn.2017.61)

McCurdy CE, Bishop JM, Williams SM, Grayson BE, Smith MS, Friedman JE \& Grove KL 2009 Maternal high-fat diet triggers lipotoxicity in the fetal livers of nonhuman primates. Journal of Clinical Investigation 119 323-335. (https://doi.org/10.1172/ JCI32661)

McEwen BS 1992 Steroid hormones: effect on brain development and function. Hormone Research 37 (Supplement 3) 1-10. (https://doi. org/10.1159/000182393)

Mendez-Mancilla A, Lima-Rogel V, Toro-Ortiz JC, Escalante-Padron F, Monsivais-Urenda AE, Noyola DE \& Salgado-Bustamante M 2018 Differential expression profiles of circulating microRNAs in newborns associated to maternal pregestational overweight and obesity. Pediatric Obesity 13 168-174. (https://doi.org/10.1111/ijpo.12247)

Mikamo E, Harada S, Nishikawa J \& Nishihara T 2003 Endocrine disruptors induce cytochrome $\mathrm{P} 450$ by affecting transcriptional regulation via pregnane $\mathrm{X}$ receptor. Toxicology and Applied Pharmacology 193 66-72. (https://doi.org/10.1016/j.taap.2003.08.001)

Miranda A \& Sousa N 2018 Maternal hormonal milieu influence on fetal brain development. Brain and Behavior 8 e00920. (https://doi. org/10.1002/brb3.920)

Moisiadis VG \& Matthews SG 2014 Glucocorticoids and fetal programming part 1: outcomes. Nature Reviews: Endocrinology 10 391-402. (https://doi.org/10.1038/nrendo.2014.73)

Morgan CP \& Bale TL 2017 Sex differences in microRNA-mRNA networks: examination of novel epigenetic programming mechanisms in the sexually dimorphic neonatal hypothalamus. Biology of Sex Differences 8 27. (https://doi.org/10.1186/s13293-017-0149-3

Morisset AS, Dube MC, Drolet R, Pelletier M, Labrie F, Luu-The V, Tremblay Y, Robitaille J, John Weisnagel S \& Tchernof A 2013 Androgens in the maternal and fetal circulation: association with insulin resistance. Journal of Maternal-Fetal and Neonatal Medicine 26 513-519. (https://doi.org/10.3109/14767058.2012.735725)

Mossa F, Latham KE, Ireland JJ \& Veiga-Lopez A 2019 Undernutrition and hyperandrogenism during pregnancy: role in programming of cardiovascular disease and infertility. Molecular Reproduction and Development 86 1255-1264. (https://doi.org/10.1002/mrd.23239)

Murabayashi N, Sugiyama T, Zhang L, Kamimoto Y, Umekawa T, MA ma N \& Sagawa N 2013 Maternal high-fat diets cause insulin resistance through inflammatory changes in fetal adipose tissue. European Journal of Obstetrics, Gynecology, and Reproductive Biology 169 39-44. (https://doi.org/10.1016/j.ejogrb.2013.02.003)

Nada SE, Thompson RC \& Padmanabhan V 2010 Developmental programming: differential effects of prenatal testosterone excess on insulin target tissues. Endocrinology 151 5165-5173. (https://doi. org/10.1210/en.2010-0666)

Neier K, Marchlewicz EH, Dolinoy DC \& Padmanabhan V 2015 Assessing human health risk to endocrine disrupting chemicals: a focus on prenatal exposures and oxidative stress. Endocrine Disruptors 3 e1069916. (https://doi.org/10.1080/23273747.2015.1069916)
Neri C \& Edlow AG 2015 Effects of maternal obesity on fetal programming: molecular approaches. Cold Spring Harbor Perspectives in Medicine 6 a026591. (https://doi.org/10.1101/cshperspect.a026591)

Nicholas LM, Rattanatray L, Maclaughlin SM, Ozanne SE, Kleemann DO, Walker SK, Morrison JL, Zhang S, Muhlhausler BS, MartinGronert MS, et al. 2013 Differential effects of maternal obesity and weight loss in the periconceptional period on the epigenetic regulation of hepatic insulin-signaling pathways in the offspring FASEB Journal 27 3786-3796. (https://doi.org/10.1096/fj.13-227918)

Nicholas LM, Morrison JL, Rattanatray L, Zhang S, Ozanne SE \& Mcmillen IC 2016 The early origins of obesity and insulin resistance: timing, programming and mechanisms. International Journal of Obesity 40 229-238. (https://doi.org/10.1038/ijo.2015.178)

Nilsson E \& Ling C 2017 DNA methylation links genetics, fetal environment, and an unhealthy lifestyle to the development of type 2 diabetes. Clinical Epigenetics 9 105. (https://doi.org/10.1186/s13148017-0399-2)

Nilsson E, Benrick A, Kokosar M, Krook A, Lindgren E, Kallman T, Martis MM, Hojlund K, Ling C \& Stener-Victorin E 2018 Transcriptional and epigenetic changes influencing skeletal muscle metabolism in women With polycystic ovary syndrome. Journal of Clinical Endocrinology \& Metabolism 103 4465-4477. (https://doi. $\operatorname{org} / 10.1210 /$ jc.2018-00935)

Nicol LE, O'brien TD, Dumesic DA, Grogan T, Tarantal AF \& Abbott DH 2014 Abnormal infant islet morphology precedes insulin resistance in PCOS-like monkeys. PLOS ONE 9 e106527. (https://doi.org/10.1371/ journal.pone.0106527)

Nivoit P, Morens C, Van Assche FA, Jansen E, Poston L, Remacle C \& Reusens B 2009 Established diet-induced obesity in female rats leads to offspring hyperphagia, adiposity and insulin resistance. Diabetologia 52 1133-1142. (https://doi.org/10.1007/s00125-0091316-9)

Noroozzadeh M, Ramezani Tehrani F, Sedaghat K, Godini A \& Azizi F 2015 The impact of prenatal exposure to a single dose of testosterone on insulin resistance, glucose tolerance and lipid profile of female rat's offspring in adulthood. Journal of Endocrinological Investigation 38 489-495. (https://doi.org/10.1007/s40618-014-0198-y)

Nugent BM \& Bale TL 2015 The omniscient placenta: metabolic and epigenetic regulation of fetal programming. Frontiers in Neuroendocrinology 39 28-37. (https://doi.org/10.1016/j. yfrne.2015.09.001)

Nyirenda MJ, Lindsay RS, Kenyon CJ, Burchell A \& Seckl JR 1998 Glucocorticoid exposure in late gestation permanently programs rat hepatic phosphoenolpyruvate carboxykinase and glucocorticoid receptor expression and causes glucose intolerance in adult offspring. Journal of Clinical Investigation 101 2174-2181. (https://doi. org/10.1172/JCI1567)

Ogawa T, Shibato J, Rakwal R, Saito T, Tamura G, Kuwagata M \& Shioda S 2014 Seeking genes responsible for developmental origins of health and disease from the fetal mouse liver following maternal food restriction. Congenital Anomalies 54 195-219. (https://doi. org/10.1111/cga.12062)

Ong TP \& Guest PC 2018 Nutritional programming effects on development of metabolic disorders in later life. Methods in Molecular Biology 1735 3-17. (https://doi.org/10.1007/978-1-4939-7614-0_1)

Ong TP \& Ozanne SE 2015 Developmental programming of type 2 diabetes: early nutrition and epigenetic mechanisms. Current Opinion in Clinical Nutrition and Metabolic Care 18 354-360. (https://doi. org/10.1097/MCO.0000000000000177)

O’Regan D, Kenyon CJ, Seckl JR \& Holmes MC 2004 Glucocorticoid exposure in late gestation in the rat permanently programs genderspecific differences in adult cardiovascular and metabolic physiology. American Journal of Physiology: Endocrinology and Metabolism 287 E863-E870. (https://doi.org/10.1152/ajpendo.00137.2004)

Osborne S, Biaggi A, Chua TE, Du Preez A, Hazelgrove K, Nikkheslat N, Previti G, Zunszain PA, Conroy S \& Pariante CM 2018 Antenatal https://joe.bioscientifica.com

https://doi.org/10.1530/JOE-20-0044
(C) 2020 Society for Endocrinology Published by Bioscientifica Ltd. Printed in Great Britain 
depression programs cortisol stress reactivity in offspring through increased maternal inflammation and cortisol in pregnancy: the Psychiatry Research and Motherhood-Depression (PRAM-D) study. Psychoneuroendocrinology 98 211-221. (https://doi.org/10.1016/j. psyneuen.2018.06.017)

Ozias MK, Li S, Hull HR, Brooks WM \& Carlson SE 2015 Relationship of circulating adipokines to body composition in pregnant women. Adipocyte 4 44-49. (https://doi.org/10.4161/adip.29805)

Padmanabhan V \& Veiga-Lopez A 2014 Reproduction Symposium: developmental programming of reproductive and metabolic health. Journal of Animal Science 92 3199-3210. (https://doi.org/10.2527/ jas.2014-7637)

Padmanabhan V, Sarma HN, Savabieasfahani M, Steckler TL \& VeigaLopez A 2010a Developmental reprogramming of reproductive and metabolic dysfunction in sheep: native steroids vs. environmental steroid receptor modulators. International Journal of Andrology $\mathbf{3 3}$ 394-404. (https://doi.org/10.1111/j.1365-2605.2009.01024.x)

Padmanabhan V, Veiga-Lopez A, Abbott DH, Recabarren SE \& Herkimer C $2010 b$ Developmental programming: impact of prenatal testosterone excess and postnatal weight gain on insulin sensitivity index and transfer of traits to offspring of overweight females. Endocrinology $\mathbf{1 5 1}$ 595-605. (https://doi.org/10.1210/en.2009-1015)

Padmanabhan V, Cardoso RC \& Puttabyatappa M 2016 Developmental programming, a pathway to disease. Endocrinology 157 1328-1340. (https://doi.org/10.1210/en.2016-1003)

Painter RC, Roseboom TJ \& Bleker OP 2005 Prenatal exposure to the Dutch famine and disease in later life: an overview. Reproductive Toxicology 20 345-352. (https://doi.org/10.1016/j. reprotox.2005.04.005)

Palou M, Konieczna J, Torrens JM, Sanchez J, Priego T, Fernandes ML, Palou A \& Pico C 2012 Impaired insulin and leptin sensitivity in the offspring of moderate caloric-restricted dams during gestation is early programmed. Journal of Nutritional Biochemistry 23 1627-1639. (https://doi.org/10.1016/j.jnutbio.2011.11.005)

Pantham P, Aye IL \& Powell TL 2015 Inflammation in maternal obesity and gestational diabetes mellitus. Placenta 36 709-715. (https://doi. org/10.1016/j.placenta.2015.04.006)

Park JH, Stoffers DA, Nicholls RD \& Simmons RA 2008 Development of type 2 diabetes following intrauterine growth retardation in rats is associated with progressive epigenetic silencing of Pdx1. Journal of Clinical Investigation 118 2316-2324. (https://doi.org/10.1172/ JCI33655)

Parsa AA \& New MI 2017 Steroid 21-hydroxylase deficiency in congenital adrenal hyperplasia. Journal of Steroid Biochemistry and Molecular Biology 165 2-11. (https://doi.org/10.1016/j.jsbmb.2016.06.015)

Pasquali R \& Oriolo C 2019 Obesity and androgens in women. Frontiers of Hormone Research 53 120-134. (https://doi.org/10.1159/000494908)

Poirier C, Desgagne V, Guerin R \& Bouchard L 2017 MicroRNAs in pregnancy and gestational diabetes mellitus: emerging role in maternal metabolic regulation. Current Diabetes Reports 1735. (https://doi.org/10.1007/s11892-017-0856-5)

Provvisiero DP, Pivonello C, Muscogiuri G, Negri M, De Angelis C, Simeoli C, Pivonello R \& Colao A 2016 Influence of bisphenol A on type 2 diabetes mellitus. International Journal of Environmental Research and Public Health 13 E989. (https://doi.org/10.3390/ ijerph13100989)

Pruis MG, Van Ewijk PA, Schrauwen-Hinderling VB \& Plosch T 2014 Lipotoxicity and the role of maternal nutrition. Acta Physiologica $\mathbf{2 1 0}$ 296-306. (https://doi.org/10.1111/apha.12171)

Puppala S, Li C, Glenn JP, Saxena R, Gawrieh S, Quinn A, Palarczyk J, Dick EJ, Nathanielsz PW \& Cox LA 2018 Primate fetal hepatic responses to maternal obesity: epigenetic signalling pathways and lipid accumulation. Journal of Physiology 596 5823-5837. (https://doi. org/10.1113/JP275422)

Puttabyatappa M, Cardoso RC \& Padmanabhan V 2016 Effect of maternal PCOS and PCOS-like phenotype on the offspring's health. Molecular and Cellular Endocrinology 435 29-39. (https://doi.org/10.1016/j. mce.2015.11.030)

Puttabyatappa M, Andriessen V, Mesquitta M, Zeng L, Pennathur S \& Padmanabhan V 2017 Developmental programming: impact of gestational steroid and metabolic milieus on mediators of insulin sensitivity in prenatal testosterone-treated female sheep. Endocrinology 158 2783-2798. (https://doi.org/10.1210/en.2017-00460)

Puttabyatappa M, Banker M, Zeng L, Goodrich JM, Domino SE, Dolinoy DC, Meeker JD, Pennathur S, Song PXK \& Padmanabhan V $2019 a$ Maternal exposure to environmental disruptors and sexuallydimorphic changes in maternal and neonatal oxidative stress. Journal of Clinical Endocrinology and Metabolism 105 dgz063. (https://doi. org/10.1210/clinem/dgz063)

Puttabyatappa M, Martin JD, Andriessen V, Stevenson M, Zeng L, Pennathur S \& Padmanabhan V 2019b Developmental programming: changes in mediators of insulin sensitivity in prenatal bisphenol A-treated female sheep. Reproductive Toxicology 85 110-122. (https:// doi.org/10.1016/j.reprotox.2019.03.002)

Puttabyatappa M \& Padmanabhan V 2017 Prenatal testosterone programming of insulin resistance in the female sheep. Advances in Experimental Medicine and Biology 1043 575-596. (https://doi. org/10.1007/978-3-319-70178-3_25)

Qi X, Yun C, Sun L, Xia J, Wu Q, Wang Y, Wang L, Zhang Y, Liang X, Wang L, et al. 2019 Gut microbiota-bile acid-interleukin-22 axis orchestrates polycystic ovary syndrome. Nature Medicine $\mathbf{2 5}$ 1225-1233. (https://doi.org/10.1038/s41591-019-0509-0)

Qiu HY, Chu YL, Li M, Sun YY \& Li HF 2005 Tyrosine phosphorylation and protein expression of insulin receptor substrate- 2 in the adipose tissue from patients with polycystic ovary syndrome. Zhonghua Fu Chan Ke Za Zhi 40 116-119.

Rabinovici J \& Jaffe RB 1990 Development and regulation of growth and differentiated function in human and subhuman primate fetal gonads. Endocrine Reviews 11 532-557. (https://doi.org/10.1210/edrv11-4-532)

Radon PA, Mcmahon MJ \& Meyer WR 1999 Impaired glucose tolerance in pregnant women with polycystic ovary syndrome. Obstetrics and Gynecology 94 194-197. (https://doi.org/10.1016/s00297844(99)00252-5)

Rae M, Grace C, Hogg K, Wilson LM, Mchaffie SL, Ramaswamy S, Maccallum J, Connolly F, Mcneilly AS \& Duncan C 2013 The pancreas is altered by in utero androgen exposure: implications for clinical conditions such as polycystic ovary syndrome (PCOS). PLOS ONE $\mathbf{8}$ e56263. (https://doi.org/10.1371/journal.pone.0056263)

Rahmani S, Pour Khalili N, Khan F, Hassani S, Ghafour-Boroujerdi E \& Abdollahi M 2018 Bisphenol A: what lies beneath its induced diabetes and the epigenetic modulation? Life Sciences 214 136-144. (https:// doi.org/10.1016/j.lfs.2018.10.044)

Rajesh P \& Balasubramanian K 2014 Phthalate exposure in utero causes epigenetic changes and impairs insulin signalling. Journal of Endocrinology 223 47-66. (https://doi.org/10.1530/JOE-14-0111)

Ramaswamy S, Grace C, Mattei AA, Siemienowicz K, Brownlee W, Maccallum J, Mcneilly AS, Duncan WC \& Rae MT 2016 Developmental programming of polycystic ovary syndrome (PCOS): prenatal androgens establish pancreatic islet alpha/beta cell ratio and subsequent insulin secretion. Scientific Reports 6 27408. (https://doi. org/10.1038/srep27408)

Rask-Madsen C \& Kahn CR 2012 Tissue-specific insulin signaling, metabolic syndrome, and cardiovascular disease. Arteriosclerosis, Thrombosis, and Vascular Biology 32 2052-2059. (https://doi. org/10.1161/ATVBAHA.111.241919)

Recabarren SE, Padmanabhan V, Codner E, Lobos A, Duran C, Vidal M, Foster DL \& Sir-Petermann T 2005 Postnatal developmental consequences of altered insulin sensitivity in female sheep treated prenatally with testosterone. American Journal of Physiology: Endocrinology and Metabolism 289 E801-E806. (https://doi. org/10.1152/ajpendo.00107.2005) https://joe.bioscientifica.com https://doi.org/10.1530/JOE-20-0044 (c) 2020 Society for Endocrinology Published by Bioscientifica Ltd.
Printed in Great Britain 
Reisch N, Arlt W \& Krone N 2011 Health problems in congenital adrenal hyperplasia due to 21-hydroxylase deficiency. Hormone Research in Paediatrics 76 73-85. (https://doi. org/10.1159/000327794)

Rinaudo P \& Wang E 2012 Fetal programming and metabolic syndrome. Annual Review of Physiology 74 107-130. (https://doi.org/10.1146/ annurev-physiol-020911-153245)

Rizza RA, Mandarino LJ, Genest J, Baker BA \& Gerich JE 1985 Production of insulin resistance by hyperinsulinaemia in man. Diabetologia $\mathbf{2 8}$ 70-75. (https://doi.org/10.1007/bf00279918)

Rodriguez-Rodriguez P, Ramiro-Cortijo D, Reyes-Hernandez CG, Lopez De Pablo AL, Gonzalez MC \& Arribas SM 2018 Implication of oxidative stress in fetal programming of cardiovascular disease. Frontiers in Physiology 9 602. (https://doi.org/10.3389/fphys.2018.00602)

Roland AV, Nunemaker CS, Keller SR \& Moenter SM 2010 Prenatal androgen exposure programs metabolic dysfunction in female mice. Journal of Endocrinology 207 213-223. (https://doi.org/10.1677/JOE10-0217)

Romeo RD 2003 Puberty: a period of both organizational and activational effects of steroid hormones on neurobehavioural development. Journal of Neuroendocrinology 15 1185-1192. (https://doi.org/10.1111/ j.1365-2826.2003.01106.x)

Rosen ED \& Spiegelman BM 2006 Adipocytes as regulators of energy balance and glucose homeostasis. Nature $\mathbf{4 4 4}$ 847-853. (https://doi. org/10.1038/nature05483)

Rosenbaum D, Haber RS \& Dunaif A 1993 Insulin resistance in polycystic ovary syndrome: decreased expression of GLUT-4 glucose transporters in adipocytes. American Journal of Physiology 264 E197-E202. (https:// doi.org/10.1152/ajpendo.1993.264.2.E197)

Ruchat SM, Hivert MF \& Bouchard L 2013 Epigenetic programming of obesity and diabetes by in utero exposure to gestational diabetes mellitus. Nutrition Reviews 71 (Supplement 1) S88-S94. (https://doi. org/10.1111/nure.12057)

Ruiz R, Jideonwo V, Ahn M, Surendran S, Tagliabracci VS, Hou Y, Gamble A, Kerner J, Irimia-Dominguez JM, Puchowicz MA, et al. 2014 Sterol regulatory element-binding protein-1 (SREBP-1) is required to regulate glycogen synthesis and gluconeogenic gene expression in mouse liver. Journal of Biological Chemistry 289 5510-5517. (https:// doi.org/10.1074/jbc.M113.541110)

Rutkowska A \& Rachon D 2014 Bisphenol A (BPA) and its potential role in the pathogenesis of the polycystic ovary syndrome (PCOS). Gynecological Endocrinology 30 260-265. (https://doi.org/10.3109/0951 3590.2013.871517)

Saben J, Lindsey F, Zhong Y, Thakali K, Badger TM, Andres A, GomezAcevedo H \& Shankar K 2014 Maternal obesity is associated with a lipotoxic placental environment. Placenta 35 171-177. (https://doi. org/10.1016/j.placenta.2014.01.003)

Saltiel AR \& Kahn CR 2001 Insulin signalling and the regulation of glucose and lipid metabolism. Nature 414 799-806. (https://doi. org/10.1038/414799a)

Samuelsson AM, Matthews PA, Argenton M, Christie MR, Mcconnell JM, Jansen EH, Piersma AH, Ozanne SE, Twinn DF, Remacle C, et al. 2008 Diet-induced obesity in female mice leads to offspring hyperphagia, adiposity, hypertension, and insulin resistance: a novel murine model of developmental programming. Hypertension 51 383-392. (https:// doi.org/10.1161/HYPERTENSIONAHA.107.101477)

Sanderson JT 2006 The steroid hormone biosynthesis pathway as a target for endocrine-disrupting chemicals. Toxicological Sciences 94 3-21. (https://doi.org/10.1093/toxsci/kfl051)

Sargis RM \& Simmons RA 2019 Environmental neglect: endocrine disruptors as underappreciated but potentially modifiable diabetes risk factors. Diabetologia 62 1811-1822. (https://doi.org/10.1007/ s00125-019-4940-z)

Sathyanarayana S, Butts S, Wang C, Barrett E, Nguyen R, Schwartz SM, Haaland W, Swan SH \& TIDES Team 2017 Early prenatal phthalate exposure, sex steroid hormones, and birth outcomes. Journal of
Clinical Endocrinology and Metabolism 102 1870-1878. (https://doi. org/10.1210/jc.2016-3837)

Schmatz M, Madan J, Marino T \& Davis J 2010 Maternal obesity: the interplay between inflammation, mother and fetus. Journal of Perinatology 30 441-446. (https://doi.org/10.1038/jp.2009.182)

Seckl JR \& Holmes MC 2007 Mechanisms of disease: glucocorticoids, their placental metabolism and fetal 'programming' of adult pathophysiology. Nature Clinical Practice: Endocrinology and Metabolism 3 479-488. (https://doi.org/10.1038/ncpendmet0515)

Selevan SG, Kimmel CA \& Mendola P 2000 Identifying critical windows of exposure for children's health. Environmental Health Perspectives 108 (Supplement 3) 451-455. (https://doi.org/10.1289/ ehp.00108s3451)

Sen S \& Simmons RA 2010 Maternal antioxidant supplementation prevents adiposity in the offspring of western diet-fed rats. Diabetes 59 3058-3065. (https://doi.org/10.2337/db10-0301)

Shanik MH, Xu Y, Skrha J, Dankner R, Zick Y \& Roth J 2008 Insulin resistance and hyperinsulinemia: is hyperinsulinemia the cart or the horse? Diabetes Care 31 (Supplement 2) S262-S268. (https://doi. org/10.2337/dc08-s264)

Sharma S, Kriebel J \& Grallert H 2017 Epigenetic regulation of glucose metabolism. Current Opinion in Clinical Nutrition and Metabolic Care 20 266-271. (https://doi.org/10.1097/MCO.0000000000000375)

Shelley P, Martin-Gronert MS, Rowlerson A, Poston L, Heales SJ, Hargreaves IP, Mcconnell JM, Ozanne SE \& Fernandez-Twinn DS 2009 Altered skeletal muscle insulin signaling and mitochondrial complex II-III linked activity in adult offspring of obese mice. American Journal of Physiology: Regulatory, Integrative and Comparative Physiology 297 R675-R681. (https://doi.org/10.1152/ajpregu.00146.2009)

Shen Q, Bi H, Yu F, Fan L, Zhu M, Jia X \& Kang J 2019 Nontargeted metabolomic analysis of skeletal muscle in a dehydroepiandrosteroneinduced mouse model of polycystic ovary syndrome. Molecular Reproduction and Development 86 370-378. (https://doi.org/10.1002/ mrd.23111)

Shimpi PC, More VR, Paranjpe M, Donepudi AC, Goodrich JM, Dolinoy DC, Rubin B \& Slitt AL 2017 Hepatic lipid accumulation and Nrf2 expression following perinatal and peripubertal exposure to bisphenol $\mathrm{A}$ in a mouse model of nonalcoholic liver disease. Environmental Health Perspectives 125 087005. (https://doi.org/10.1289/EHP664)

Simar D, Chen H, Lambert K, Mercier J \& Morris MJ 2012 Interaction between maternal obesity and post-natal over-nutrition on skeletal muscle metabolism. Nutrition, Metabolism, and Cardiovascular Diseases 22 269-276. (https://doi.org/10.1016/j.numecd.2010.11.007)

Singh R, Pearson E, Avery PJ, Mccarthy MI, Levy JC, Hitman GA, Sampson M, Walker M \& Hattersley AT 2006 Reduced beta cell function in offspring of mothers with young-onset type 2 diabetes. Diabetologia 49 1876-1880. (https://doi.org/10.1007/s00125-006-0285-5)

Sir-Petermann T, Maliqueo M, Angel B, Lara HE, Perez-Bravo F \& Recabarren SE 2002 Maternal serum androgens in pregnant women with polycystic ovarian syndrome: possible implications in prenatal androgenization. Human Reproduction 17 2573-2579. (https://doi. org/10.1093/humrep/17.10.2573)

Sir-Petermann T, Echiburu B, Maliqueo MM, Crisosto N, Sanchez F, Hitschfeld C, Carcamo M, Amigo P \& Perez-Bravo F 2007 Serum adiponectin and lipid concentrations in pregnant women with polycystic ovary syndrome. Human Reproduction 22 1830-1836. (https://doi.org/10.1093/humrep/dem090)

Sir-Petermann T, Codner E, Perez V, Echiburu B, Maliqueo M, Ladron De Guevara A, Preisler J, Crisosto N, Sanchez F, Cassorla F, et al. 2009 Metabolic and reproductive features before and during puberty in daughters of women with polycystic ovary syndrome. Journal of Clinical Endocrinology and Metabolism 94 1923-1930. (https://doi. org/10.1210/jc.2008-2836)

Song W, Puttabyatappa M, Zeng L, Vazquez D, Pennathur S \& Padmanabhan V 2020 Developmental programming: prenatal bisphenol A treatment disrupts mediators of placental function https://joe.bioscientifica.com

https://doi.org/10.1530/JOE-20-0044 (c) 2020 Society for Endocrinology Published by Bioscientifica Ltd. Printed in Great Britain 
in sheep. Chemosphere 243 125301. (https://doi.org/10.1016/j. chemosphere.2019.125301)

Stanner SA, Bulmer K, Andres C, Lantseva OE, Borodina V, Poteen VV \& Yudkin JS 1997 Does malnutrition in utero determine diabetes and coronary heart disease in adulthood? Results from the Leningrad siege study, a cross sectional study. BMJ 315 1342-1348. (https://doi. org/10.1136/bmj.315.7119.1342)

Stel J \& Legler J 2015 The role of epigenetics in the latent effects of early life exposure to obesogenic endocrine disrupting chemicals. Endocrinology 156 3466-3472. (https://doi.org/10.1210/en.2015-1434)

Stener-Victorin E, Ploj K, Larsson BM \& Holmang A 2005 Rats with steroid-induced polycystic ovaries develop hypertension and increased sympathetic nervous system activity. Reproductive Biology and Endocrinology 3 44. (https://doi.org/10.1186/1477-7827-3-44)

Stepto NK, Moreno-Asso A, Mcilvenna LC, Walters KA \& Rodgers RJ 2019 Molecular mechanisms of insulin resistance in polycystic ovary syndrome: unraveling the conundrum in skeletal muscle? Journal of Clinical Endocrinology and Metabolism 104 5372-5381. (https://doi. org/10.1210/jc.2019-00167)

Strakovsky RS, Wang H, Engeseth NJ, Flaws JA, Helferich WG, Pan YX \& Lezmi S 2015 Developmental bisphenol A (BPA) exposure leads to sex-specific modification of hepatic gene expression and epigenome at birth that may exacerbate high-fat diet-induced hepatic steatosis. Toxicology and Applied Pharmacology 284 101-112. (https://doi. org/10.1016/j.taap.2015.02.021)

Strauss 3rd JF, Martinez F \& Kiriakidou M 1996 Placental steroid hormone synthesis: unique features and unanswered questions. Biology of Reproduction 54 303-311. (https://doi.org/10.1095/biolreprod54.2.303)

Sun M, Maliqueo M, Benrick A, Johansson J, Shao R, Hou L, Jansson T, Wu X \& Stener-Victorin E 2012 Maternal androgen excess reduces placental and fetal weights, increases placental steroidogenesis, and leads to long-term health effects in their female offspring. American Journal of Physiology: Endocrinology and Metabolism 303 E1373-E1385. (https://doi.org/10.1152/ajpendo.00421.2012)

Tabb MM \& Blumberg B 2006 New modes of action for endocrinedisrupting chemicals. Molecular Endocrinology 20 475-482. (https:// doi.org/10.1210/me.2004-0513)

Takeuchi T, Tsutsumi O, Ikezuki Y, Takai Y \& Taketani Y 2004 Positive relationship between androgen and the endocrine disruptor, bisphenol $\mathrm{A}$, in normal women and women with ovarian dysfunction. Endocrine Journal 51 165-169. (https://doi.org/10.1507/endocrj.51.165)

Tamhane S, Rodriguez-Gutierrez R, Iqbal AM, Prokop LJ, Bancos I, Speiser PW \& Murad MH 2018 Cardiovascular and metabolic outcomes in congenital adrenal hyperplasia: a systematic review and meta-analysis. Journal of Clinical Endocrinology and Metabolism 103 4097-4103. (https://doi.org/10.1210/jc.2018-01862)

Tarnow P, Tralau T \& Luch A 2019 Chemical activation of estrogen and aryl hydrocarbon receptor signaling pathways and their interaction in toxicology and metabolism. Expert Opinion on Drug Metabolism and Toxicology 15 219-229. (https://doi.org/10.1080/17425255.2019.156 9627)

Taylor PD, Mcconnell J, Khan IY, Holemans K, Lawrence KM, AsareAnane H, Persaud SJ, Jones PM, Petrie L, Hanson MA, et al. 2005 Impaired glucose homeostasis and mitochondrial abnormalities in offspring of rats fed a fat-rich diet in pregnancy. American Journal of Physiology: Regulatory, Integrative and Comparative Physiology 288 R134-R139. (https://doi.org/10.1152/ajpregu.00355.2004)

Taylor KW, Novak RF, Anderson HA, Birnbaum LS, Blystone C, Devito M, Jacobs D, Kohrle J, Lee DH, Rylander L, et al. 2013 Evaluation of the association between persistent organic pollutants (POPs) and diabetes in epidemiological studies: a national toxicology program workshop review. Environmental Health Perspectives 121 774-783. (https://doi. org/10.1289/ehp.1205502)

Tchernof A \& Despres JP 2013 Pathophysiology of human visceral obesity: an update. Physiological Reviews 93 359-404. (https://doi. org/10.1152/physrev.00033.2011)
Tenorio MB, Ferreira RC, Moura FA, Bueno NB, De Oliveira ACM \& Goulart MOF 2019 Cross-talk between oxidative stress and inflammation in preeclampsia. Oxidative Medicine and Cellular Longevity 2019 8238727. (https://doi.org/10.1155/2019/8238727)

Tetel MJ, De Vries GJ, Melcangi RC, Panzica G \& O'mahony SM 2018 Steroids, stress and the gut microbiome-brain axis. Journal of Neuroendocrinology 30 e12548. (https://doi.org/10.1111/jne.12548)

Thompson LP \& Al-Hasan Y 2012 Impact of oxidative stress in fetal programming. Journal of Pregnancy 2012 1-8. (https://doi. org $/ 10.1155 / 2012 / 582748)$

Thornburg KL, O'tierney PF \& Louey S 2010 Review: The placenta is a programming agent for cardiovascular disease. Placenta 31 (Supplement) S54-S59. (https://doi.org/10.1016/j.placenta.2010.01.002)

Todd SE, Oliver MH, Jaquiery AL, Bloomfield FH \& Harding JE 2009 Periconceptional undernutrition of ewes impairs glucose tolerance in their adult offspring. Pediatric Research 65 409-413. (https://doi. org/10.1203/PDR.0b013e3181975efa)

True CA, Takahashi DL, Burns SE, Mishler EC, Bond KR, Wilcox MC, Calhoun AR, Bader LA, Dean TA, Ryan ND, et al. 2017 Chronic combined hyperandrogenemia and western-style diet in young female rhesus macaques causes greater metabolic impairments compared to either treatment alone. Human Reproduction 32 1880-1891. (https:// doi.org/10.1093/humrep/dex246)

Vaiserman AM 2017 Early-life nutritional programming of type 2 diabetes: experimental and quasi-experimental evidence. Nutrients 9 E236. (https://doi.org/10.3390/nu9030236)

Vaiserman A \& Lushchak O 2019 Developmental origins of type 2 diabetes: focus on epigenetics. Ageing Research Reviews $\mathbf{5 5} 100957$. (https://doi.org/10.1016/j.arr.2019.100957)

Valko M, Leibfritz D, Moncol J, Cronin MT, Mazur M \& Telser J 2007 Free radicals and antioxidants in normal physiological functions and human disease. International Journal of Biochemistry and Cell Biology 39 44-84. (https://doi.org/10.1016/j.biocel.2006.07.001)

Van Der Meer T 2015 Multigenerational effects of maternal bisphenol A exposure on hepatic gene expression in mice. Thesis. Groningen, University of Groningen. (available at: http://scripties.umcg.eldoc. ub.rug.nl/root/geneeskunde/2015/MeerTvander/)

Van Houten EL, Kramer P, Mcluskey A, Karels B, Themmen AP \& Visser JA 2012 Reproductive and metabolic phenotype of a mouse model of PCOS. Endocrinology 153 2861-2869. (https://doi.org/10.1210/ en.2011-1754)

Varlamov O, Bethea CL \& Roberts Jr CT 2015 Sex-specific differences in lipid and glucose metabolism. Frontiers in Endocrinology 5241. (https://doi.org/10.3389/fendo.2014.00241)

Veiga-Lopez A, Moeller J, Patel D, Ye W, Pease A, Kinns J \& Padmanabhan V 2013 Developmental programming: impact of prenatal testosterone excess on insulin sensitivity, adiposity, and free fatty acid profile in postpubertal female sheep. Endocrinology 154 1731-1742. (https://doi.org/10.1210/en.2012-2145)

Veiga-Lopez A, Pennathur S, Kannan K, Patisaul HB, Dolinoy DC, Zeng L \& Padmanabhan V 2015 Impact of gestational bisphenol A on oxidative stress and free fatty acids: human association and interspecies animal testing studies. Endocrinology 156 911-922. (https://doi.org/10.1210/en.2014-1863)

Veiga-Lopez A, Moeller J, Sreedharan R, Singer K, Lumeng C, Ye W, Pease A \& Padmanabhan V 2016 Developmental programming: interaction between prenatal BPA exposure and postnatal adiposity on metabolic variables in female sheep. American Journal of Physiology: Endocrinology and Metabolism 310 E238-E247. (https://doi. org/10.1152/ajpendo.00425.2015)

Vejrazkova D, Vcelak J, Vankova M, Lukasova P, Bradnova O, Halkova T, Kancheva R \& Bendlova B 2014 Steroids and insulin resistance in pregnancy. Journal of Steroid Biochemistry and Molecular Biology 139 122-129. (https://doi.org/10.1016/j.jsbmb.2012.11.007)

Venkatesh KK, Meeker JD, Cantonwine DE, Mcelrath TF \& Ferguson KK 2019 Association of antenatal depression with oxidative stress and https://joe.bioscientifica.com

https://doi.org/10.1530/JOE-20-0044 (c) 2020 Society for Endocrinology Published by Bioscientifica Ltd. Printed in Great Britain 
impact on spontaneous preterm birth. Journal of Perinatology 39 554-562. (https://doi.org/10.1038/s41372-019-0317-x)

Visiedo F, Bugatto F, Sanchez V, Cozar-Castellano I, Bartha JL \& Perdomo G 2013 High glucose levels reduce fatty acid oxidation and increase triglyceride accumulation in human placenta. American Journal of Physiology: Endocrinology and Metabolism 305 E205-E212. (https://doi.org/10.1152/ajpendo.00032.2013)

Vogt MC \& Bruning JC 2013 CNS insulin signaling in the control of energy homeostasis and glucose metabolism - from embryo to old age. Trends in Endocrinology and Metabolism 24 76-84. (https://doi. org/10.1016/j.tem.2012.11.004)

Vyas AK, Hoang V, Padmanabhan V, Gilbreath E \& Mietelka KA 2016 Prenatal programming: adverse cardiac programming by gestational testosterone excess. Scientific Reports 6 28335. (https://doi. org/10.1038/srep28335)

Wadhwa PD, Buss C, Entringer S \& Swanson JM 2009 Developmental origins of health and disease: brief history of the approach and current focus on epigenetic mechanisms. Seminars in Reproductive Medicine 27 358-368. (https://doi.org/10.1055/s-0029-1237424)

Wakui S, Yokoo K, Takahashi H, Muto T, Suzuki Y, Kanai Y, Hano H, Furusato M \& Endou H 2006 Prenatal 3,3', 4, 4', 5-pentachlorobiphenyl exposure modulates induction of rat hepatic CYP $1 \mathrm{~A} 1,1 \mathrm{~B} 1$, and $\mathrm{AhR}$ by 7,12-dimethylbenz[a]anthracene. Toxicology and Applied Pharmacology 210 200-211. (https://doi.org/10.1016/j.taap.2005.04.022)

Wang Y, Sun Y \& Qiu H 2004 Expression of resistin mRNA in adipose tissue of rat model with polycystic ovarian syndrome and its implication. Journal of Huazhong University of Science and Technology: Medical Sciences 24 621-624. (https://doi.org/10.1007/ bf02911374)

Wang ZC, Gu XF, Yang DZ \& Kuang JQ 2005 Expression of insulin receptor substrate 1 and phosphorylation of tyrosine in adipose tissue of polycystic ovary syndrome. Zhonghua Fu Chan Ke Za Zhi 40 120-123.

Wang M, Monaco MH \& Donovan SM 2016 Impact of early gut microbiota on immune and metabolic development and function. Seminars in Fetal and Neonatal Medicine 21 380-387. (https://doi. org/10.1016/j.siny.2016.04.004)

Wang HH, Zhou CL, Lv M, Yang Q, Li JX, Hou M, Lin J, Liu XM, Wu YT, Sheng JZ, et al. 2018 Prenatal high estradiol exposure induces sexspecific and dietarily reversible insulin resistance through decreased hypothalamic INSR. Endocrinology 159 465-476. (https://doi. org/10.1210/en.2017-03017)

Watkins DJ, Ferguson KK, Anzalota Del Toro LV, Alshawabkeh AN, Cordero JF \& Meeker JD 2015 Associations between urinary phenol and paraben concentrations and markers of oxidative stress and inflammation among pregnant women in Puerto Rico. International Journal of Hygiene and Environmental Health 218 212-219. (https://doi. $\operatorname{org} / 10.1016 / j .1 j h e h .2014 .11 .001)$

Weinberg JM 2006 Lipotoxicity. Kidney International 70 1560-1566. (https://doi.org/10.1038/sj.ki.5001834)

Whyte JJ, Alexenko AP, Davis AM, Ellersieck MR, Fountain ED \& Rosenfeld CS 2007 Maternal diet composition alters serum steroid and free fatty acid concentrations and vaginal $\mathrm{pH}$ in mice. Journal of Endocrinology 192 75-81. (https://doi.org/10.1677/JOE-06-0095)

Wooding P \& Burton G 2008 Comparative Placentation: Structures, Functions and Evolution. Berlin: Germany: Springer Science \& Business Media.

Woodruff TJ, Zota AR \& Schwartz JM 2011 Environmental chemicals in pregnant women in the United States: NHANES 2003-2004. Environmental Health Perspectives 119 878-885. (https://doi. org/10.1289/ehp.1002727)
Wu L, Lu Y, Jiao Y, Liu B, Li S, Li Y, Xing F, Chen D, Liu X, Zhao J, et al. 2016 Paternal psychological stress reprograms hepatic gluconeogenesis in offspring. Cell Metabolism 23 735-743. (https:// doi.org/10.1016/j.cmet.2016.01.014)

Xu RA, Mao B, Li S, Liu J, Li X, Li H, Su Y, Hu G, Lian QQ \& Ge RS 2016 Structure-activity relationships of phthalates in inhibition of human placental 3beta-hydroxysteroid dehydrogenase 1 and aromatase. Reproductive Toxicology 61 151-161. (https://doi.org/10.1016/j. reprotox.2016.04.004)

Yajnik CS, Deshpande SS, Jackson AA, Refsum H, Rao S, Fisher DJ, Bhat DS, Naik SS, Coyaji KJ, Joglekar CV, et al. 2008 Vitamin B12 and folate concentrations during pregnancy and insulin resistance in the offspring: the Pune Maternal Nutrition study. Diabetologia 51 29-38. (https://doi.org/10.1007/s00125-007-0793-y)

Yan X, Zhu MJ, Xu W, Tong JF, Ford SP, Nathanielsz PW \& Du M 2010 Up-regulation of toll-like receptor 4/nuclear factor-kappaB signaling is associated with enhanced adipogenesis and insulin resistance in fetal skeletal muscle of obese sheep at late gestation. Endocrinology 151 380-387. (https://doi.org/10.1210/en.2009-0849)

Yan X, Dai X, Wang J, Zhao N, Cui Y \& Liu J 2013 Prenatal androgen excess programs metabolic derangements in pubertal female rats. Journal of Endocrinology 217 119-129. (https://doi.org/10.1530/JOE-12-0577)

Yanes LL, Romero DG, Moulana M, Lima R, Davis DD, Zhang H, Lockhart R, Racusen LC \& Reckelhoff JF 2011 Cardiovascular-renal and metabolic characterization of a rat model of polycystic ovary syndrome. Gender Medicine 8 103-115. (https://doi.org/10.1016/j.genm.2010.11.013)

Zhang S, Rattanatray L, Morrison JL, Nicholas LM, Lie S \& Mcmillen IC 2011 Maternal obesity and the early origins of childhood obesity: weighing up the benefits and costs of maternal weight loss in the periconceptional period for the offspring. Experimental Diabetes Research 2011 585749. (https://doi.org/10.1155/2011/585749)

Zheng J, Xiao X, Zhang Q, Wang T, Yu M \& Xu J 2017 Maternal lowprotein diet modulates glucose metabolism and hepatic microRNAs expression in the early life of offspring dagger. Nutrients 9 E205. (https://doi.org/10.3390/nu9030205)

Zheng Y, Ley SH \& Hu FB 2018 Global aetiology and epidemiology of type 2 diabetes mellitus and its complications. Nature Reviews: Endocrinology 14 88-98. (https://doi.org/10.1038/nrendo.2017.151)

Zhou W, Liu J, Liao L, Han S \& Liu J 2008 Effect of bisphenol A on steroid hormone production in rat ovarian theca-interstitial and granulosa cells. Molecular and Cellular Endocrinology 283 12-18. (https://doi. org/10.1016/j.mce.2007.10.010)

Zhou Z, Sun B, Li X \& Zhu C 2018 DNA methylation landscapes in the pathogenesis of type 2 diabetes mellitus. Nutrition and Metabolism 15 47. (https://doi.org/10.1186/s12986-018-0283-x)

Zhu C, Yang H, Geng Q, Ma Q, Long Y, Zhou C \& Chen M 2015 Association of oxidative stress biomarkers with gestational diabetes mellitus in pregnant women: a case-control study. PLOS ONE 10 e0126490. (https://doi.org/10.1371/journal.pone.0126490)

Zijlmans MA, Korpela K, Riksen-Walraven JM, De Vos WM \& De Weerth C 2015 Maternal prenatal stress is associated with the infant intestinal microbiota. Psychoneuroendocrinology 53 233-245. (https:// doi.org/10.1016/j.psyneuen.2015.01.006)

Zota AR, Geller RJ, Romano LE, Coleman-Phox K, Adler NE, Parry E, Wang M, Park JS, Elmi AF, Laraia BA, et al. 2018 Association between persistent endocrine-disrupting chemicals (PBDEs, OH-PBDEs, PCbs, and PFASs) and biomarkers of inflammation and cellular aging during pregnancy and postpartum. Environment International 115 9-20. (https://doi.org/10.1016/j.envint.2018.02.044)

Received in final form 17 March 2020

Accepted 2 April 2020

Accepted Manuscript published online 2 April 2020 https://joe.bioscientifica.com https://doi.org/10.1530/JOE-20-0044 (c) 2020 Society for Endocrinology Published by Bioscientifica Ltd.
Printed in Great Britain 